L. V. Danyushevsky $\cdot$ F. N. Della-Pasqua $\cdot$ S. Sokolov

\title{
Re-equilibration of melt inclusions trapped by magnesian olivine phenocrysts from subduction-related magmas: petrological implications
}

Received: 2 November 1998 / Accepted: 27 September 1999

\begin{abstract}
We describe and model a potential re-equilibration process that can affect compositions of melt inclusions in magnesian olivine phenocrysts. This process, referred to as "Fe-loss", can operate during natural pre-eruptive cooling of host magma and results in lower $\mathrm{FeO}^{\mathrm{t}}$ and higher $\mathrm{MgO}$ contents within the initially trapped volume of inclusion. The extent of Fe-loss is enhanced by large temperature intervals of magma cooling before eruption. The compositions of homogenised melt inclusions in olivine phenocrysts from several subduction-related suites demonstrate that (1) Fe-loss is a common process, (2) the maximum observed degree of re-equilibration varies between suites, and (3) within a single sample, variable degrees of re-equilibration can be recorded by melt inclusions trapped in olivine phenocrysts of identical composition. Our modelling also demonstrates that the re-equilibration process is fast going to completion, in the largest inclusions in the most magnesian phenocrysts it is completed within 2 years. The results we obtained indicate that the possibility of Fe-loss must be considered when estimating compositions of parental subduction-related magmas from naturally quenched glassy melt inclusions in magnesian olivine phenocrysts. Compositions calculated from glassy inclusions affected by Fe-loss will inherit not only erroneously low $\mathrm{FeO}^{\mathrm{t}}$ contents, but also low $\mathrm{MgO}$ due to the inherited higher $\mathrm{Mg} \#$ of the residual melt in reequilibrated inclusions. We also demonstrate that due to the higher $\mathrm{MgO}$ contents of homogenised melt inclusions affected by Fe-loss, homogenisation temperatures
\end{abstract}

L.V. Danyushevsky $(\bowtie) \cdot$ F.N. Della-Pasqua

School of Earth Sciences,

University of Tasmania, GPO Box 252-79,

Hobart, Tasmania, 7001, Australia

e-mail: L.Dan@utas.edu.au

Tel.: +61-3-62262429, Fax: +61-3-62232547

S. Sokolov

CSIRO Division of Marine Research,

GPO Box 1538, Hobart, Tasmania, 7001, Australia

Editorial responsibility: T. L. Grove achieved in heating experiments will be higher than original trapping temperatures. The extent of overheating will increase depending on the degree of re-equilibration, and can reach up to $50{ }^{\circ} \mathrm{C}$ in cases where complete re-equilibration occurs over a cooling interval of $200{ }^{\circ} \mathrm{C}$.

\section{Introduction}

Determining the primary melt compositions of subduction-related magmatic suites has been a long-standing petrological problem (e.g. Crawford et al. 1987). Such studies are hampered by the rare eruption of primitive near-primary magmas in supra-subduction settings. Whole rock compositions of subduction-related volcanics commonly reflect a significant amount of fractionation, usually coupled with assimilation and magma mixing. An additional factor complicating the determination of initial melt compositions is the widespread accumulation of phenocrysts in erupting melts. This process accounts for the strongly porphyritic nature of primitive (high-MgO) subduction-related magmatic rocks, and complicates the reconstruction of primary magma compositions even when primitive rocks are available (e.g. Walker and Cameron 1983; Ramsay et al. 1984; Eggins 1993; Sobolev and Danyushevsky 1994; Kamenetsky et al. 1995b). These difficulties have stimulated interest in studies of melt inclusions trapped by primitive phenocrysts. Such inclusions may represent 'snapshots' of magmatic conditions, and they are increasingly used to establish the chemical characteristics and early evolution of primitive subduction-related melts (e.g. Anderson 1974; Roedder 1984; Danyushevsky et al. 1992; Sobolev et al. 1993; Sisson and Layne 1993; Sobolev and Danyushevsky 1994; Sisson and Bronto 1998; Lee and Stern 1998).

It is also well recognised that the original compositions of melt inclusions are readily modified after trapping by crystallisation of the host on the walls and other daughter phases within the inclusions prior to eruption. 
Such modifications can be experimentally reversed (e.g. Sobolev et al. 1980; Sinton et al. 1993) by remelting these daughter and host wall phases. A less recognised process affecting the composition of melt inclusions during natural cooling is re-equilibration with the host phenocryst, or even with the host magma. If such reequilibration occurs, the bulk composition of all phases within the inclusion is changed and thus the composition of the originally trapped melt cannot be reversed experimentally.

This study focuses on a re-equilibration process that modifies the composition of melt inclusions in magnesian olivine phenocrysts. These phenocrysts are of particular interest in studies of primitive magmas as they grew from the least fractionated liquids. The re-equilibration process, hereafter called "Fe-loss", has been previously recognised by several authors (e.g. Gurenko et al. 1988, 1992; Danyushevsky et al. 1992; Sobolev and Danyushevsky 1994) and mostly results in significantly lower $\mathrm{FeO}^{\mathrm{t}}$ and higher $\mathrm{MgO}$ contents within the initial volume of trapped inclusions. Homogenised inclusions thus have significantly higher $\mathrm{Mg} \#(=100 * \mathrm{Mg} /$ $\left.\left(\mathrm{Mg}+\mathrm{Fe}^{2+}\right)\right)$ compared to the originally trapped melts. Fe-loss also affects commonly used estimations of parental magma compositions from the compositions of naturally quenched glassy melt inclusions.

In this paper, we model Fe-loss and demonstrate that the extent of process is governed by (1) the cooling rate of the host crystal in the magma chamber prior to eruption and (2) the temperature difference between trapping and quenching of inclusions during eruption. A similar re-equilibration process affecting spinel inclusions in olivine phenocrysts has been described by Scowen et al. (1991).

\section{Homogenisation of melt inclusions during heating experiments}

The critical aspect of experimental studies performed on melt inclusions is their homogenisation. Once a melt inclusion is trapped, the decreasing temperature of the magma during natural cooling causes crystallisation of the trapped melt, which is saturated in the host mineral at the moment of trapping. The host mineral always crystallises as a rim on the walls of the inclusion because the pre-existing phase boundary (inclusion wall) has a lower nucleation energy (e.g. Roedder 1979). Other daughter minerals can also crystallise within inclusions.

In the case of low pressure fractionation of relatively primitive magmas $(\mathrm{MgO}>6-7 \mathrm{wt} \%)$, crystallisation within olivine-hosted melt inclusions causes decreasing pressure inside them, because olivine is denser than melt. If the trapped melt was fluid saturated (inferred for most subduction-related magmas at relatively low pressures based on the presence of primary fluid inclusions in phenocrysts), decreasing pressure will immediately cause nucleation of a fluid bubble. This is because fluid solubility in the melt is strongly pressure dependent. In ideal cases, when inclusions behave as a closed system, experimental reheating will cause melting of daughter crystals formed during magma cooling and this in turn increases the pressure inside the inclusions. If pressure inside an inclusion reaches its original value at the moment of trapping (i.e. all daughter crystals and host wall rim are melted), the fluid bubble will disappear into the melt, a process called homogenisation. Ideally, the inclusion composition at this stage is equal to the composition of the melt at the moment of trapping, and the temperature of homogenisation matches the temperature of trapping.

In practice, however, conducting homogenisation experiments at $1 \mathrm{~atm}$ causes an increase in inclusion volumes at high temperature (and consequently a decrease in pressure inside inclusions) due to the positive value of bulk modulus of olivine. Tait (1992) has shown that this decrease in pressure is proportional to the trapping pressure and reaches approximately $10 \%$ at $\sim 0.3 \mathrm{GPa}$. This will cause overheating (i.e. melting of a larger proportion of olivine from the walls of the inclusion than that crystallised during natural cooling) to achieve homogenisation. However, the effect appears to be within the accuracy of the homogenisation technique $\left( \pm 15{ }^{\circ} \mathrm{C}\right.$, Sobolev et al. 1989), as demonstrated by a number of successful studies of homogenisation of melt inclusions in cotectic systems. More importantly, homogenisation of $\mathrm{H}_{2} \mathrm{O}$-bearing melt inclusions trapped by olivine phenocrysts is often difficult to achieve due to dissociation of $\mathrm{H}_{2} \mathrm{O}$ by rapid diffusion of hydrogen from inclusions during experiments at high temperature (Sobolev and Danyushevsky 1994). The dissociation of $\mathrm{H}_{2} \mathrm{O}$ can cause overheating or even prevent dissolution of the fluid bubble altogether. In the cases when the dissociation of $\mathrm{H}_{2} \mathrm{O}$ is significant, therefore, heating may be conducted until the moment of complete melting of the daughter crystals inside inclusions. Such experiments cannot yield correct crystallisation temperatures and absolute concentrations of elements, but can provide information on the ratios of elements incompatible to olivine. Inclusions quenched in such experiments are hereafter called reheated inclusions.

\section{Evidence for Fe-loss in melt inclusions in olivine phenocrysts}

Some subduction-related volcanic suites with primitive, high- $\mathrm{MgO}$ rocks display major element trends that may be accounted for by crystal fractionation and accumulation from or in a common parental magma (e.g. Walker and Cameron 1983; Eggins 1993; Sobolev and Danyushevsky 1994). The high-MgO end-members of such suites usually reflect the accumulation of olivine ( \pm pyroxene) phenocrysts in a relatively more evolved erupting host magma.

Figure 1 shows the Western Group of Tongan high$\mathrm{Ca}$ boninites as an example (Sobolev and Danyushevsky 1994). Compositions of homogenised inclusions in 


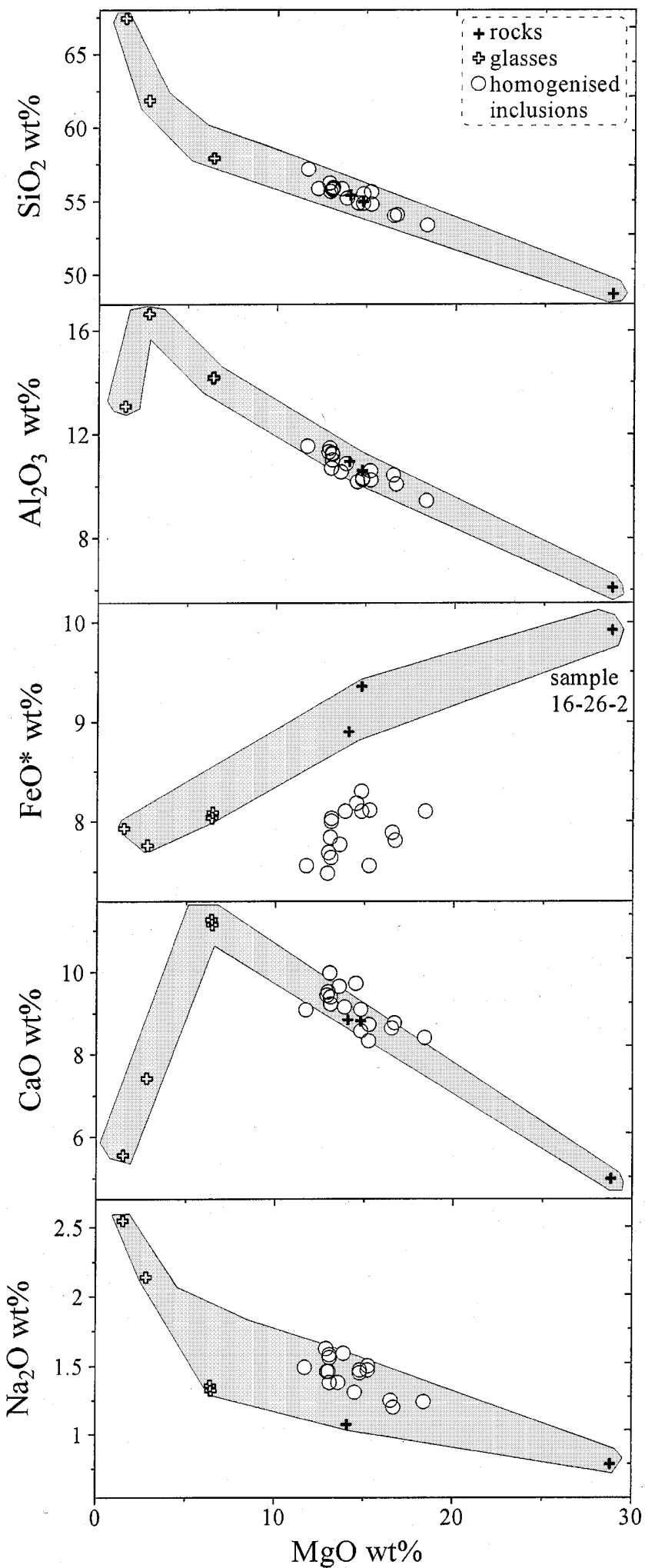

Fig. 1 Comparison between the composition of rocks and pillow-rim glasses of the Western Group of Tongan high-Ca boninites (crosses, data from Sobolev and Danyushevsky 1994) and homogenized melt inclusions in olivine phenocrysts $\left(\mathrm{Fo}_{89.5-92}\right)$ from this suite (open circles, data from Sobolev and Danyushevsky 1994; Danyushevsky, unpublished). Note that $\mathrm{FeO}^{\mathrm{t}}$ contents are low in melt inclusions, whereas other major elements overlap with the rock trend. See text for discussion magnesian olivine phenocrysts $\left(\mathrm{Fo}_{89.5-92}\right)$ from this suite are compared with the whole rock compositions in Fig. 1. The inclusions clearly have lower $\mathrm{FeO}^{\mathrm{t}}$ contents compared to pillow-rim glass and whole rock compositions, but other major elements overlap. Sobolev and Danyushevsky (1994) noted that the inclusions, when compared with their host olivines, have significantly higher $\mathrm{K}_{\mathrm{D}}(>0.36)$ than those $(0.30 \pm 0.03$, e.g. Roeder and Emslie 1970; Ulmer 1989) determined experimentally. Sobolev and Danyushevsky (1994) also noted that the combination of low $\mathrm{FeO}^{\mathrm{t}}$ and high $\mathrm{K}_{\mathrm{D}}$ values cannot result from overheating of the melt inclusions during experiments. Thus these authors concluded that low $\mathrm{FeO}^{\mathrm{t}}$ contents of the inclusions are not representative of trapped liquid compositions.

However, the most direct evidence for Fe-loss comes from diffusion profiles of $\mathrm{Fe}$ and $\mathrm{Mg}$ in the host olivine adjacent to low-FeO ${ }^{t}$ inclusions (Fig. 2a). As we show below, these profiles reflect re-equilibration between melt inclusion and its host.

Contrasting styles of variations of $\mathrm{FeO}^{\mathrm{t}}$ contents in melt inclusions in olivine phenocrysts from subduction-related suites

\section{Merelava Island, Vanuatu arc}

The petrology and geochemistry of this suite are fully described by Barsdell (1988) and Della-Pasqua and Varne (1997). The suite consists of a differentiated sequence ranging from ankaramitic magnesian end-members to basaltic andesites and andesites, with whole rock $\mathrm{MgO}$ contents varying from 4 to $14 \mathrm{wt} \%$ (Fig. 3a). Melt inclusion analyses plotted in Fig. 3a, b are from olivine phenocrysts $\left(\mathrm{Fo}_{82-91}\right)$ in sample 31551 (10.67 wt\% $\mathrm{MgO}$ ). This sample is among the most magnesian in the suite, and contains abundant olivine $\left(\mathrm{Fo}_{91-78}\right)$ and clinopyroxene phenocrysts.

$\mathrm{FeO}^{\mathrm{t}}$ contents of reheated melt inclusions from the sample 31551 have a range $(\sim 5-9 \mathrm{wt} \%)$ that is much larger than the whole rock trend $(\sim 8-10 \mathrm{wt} \%)$ (Fig. 3a). The difference between $\mathrm{FeO}^{t}$ in inclusions and the whole rock clearly increases with increasing Fo of the host olivine (Fig. 3b), resulting in a negative correlation between $\mathrm{Fo}$ and the lowest $\mathrm{FeO}^{\mathrm{t}}$ in melt inclusions. Melt inclusions with $\mathrm{FeO}^{\mathrm{t}}$ contents similar to those in rock samples span the entire range of olivine compositions.

\section{Ulakan Formation, Sunda arc}

The petrology and geochemistry of this suite are fully described in Della-Pasqua and Varne (1997, and references therein). The Ulakan suite is an ankaramitebasalt fractionation sequence with a range of $\mathrm{MgO}$ from 7 to $18 \mathrm{wt} \%$, and $\mathrm{FeO}$ from 10 to $11 \mathrm{wt} \%$ (Fig. 3c). The most primitive sample in this suite (sample 67424) has abundant olivine $\left(\mathrm{Fo}_{92-74}\right)$ and clinopyroxene pheno- 
Inclusion

16-26-2/O-64a

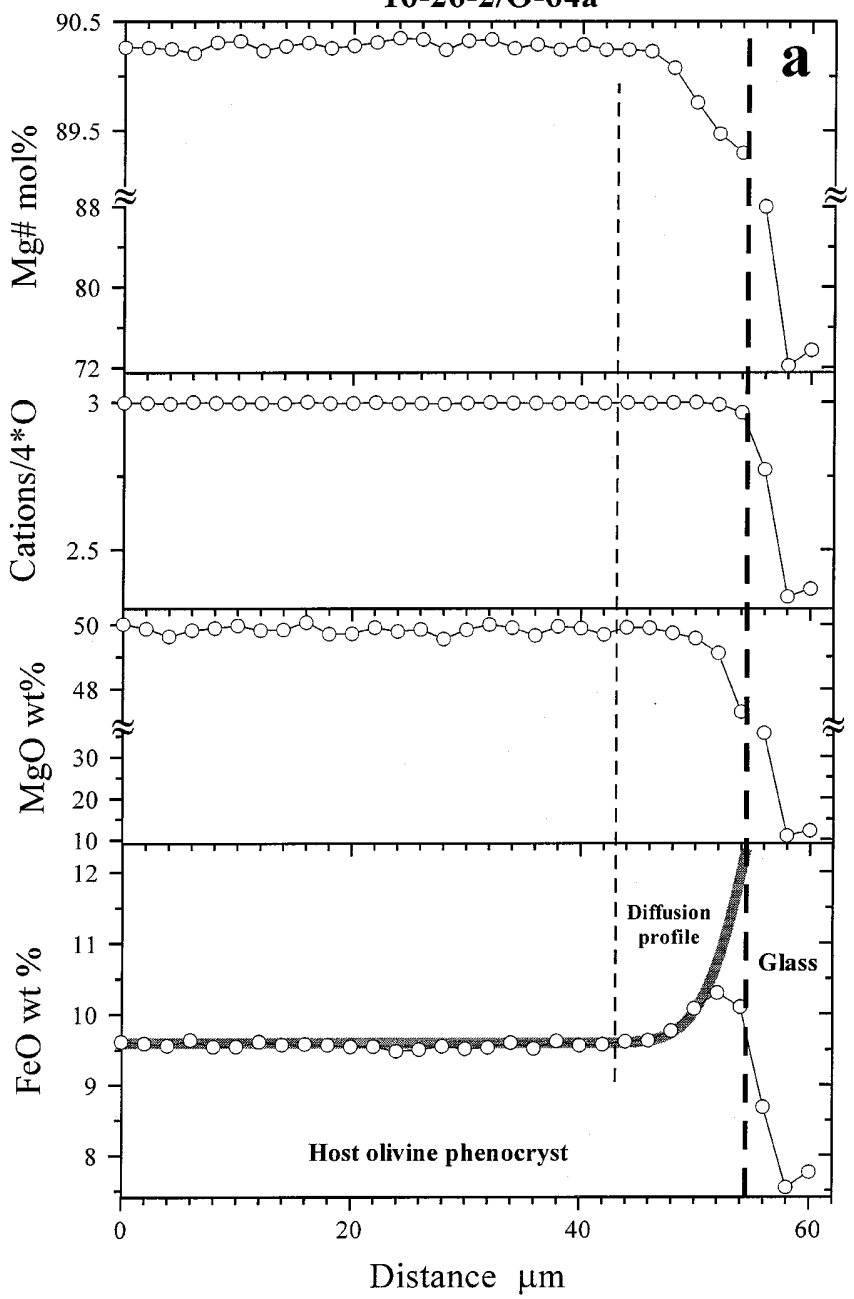

Fig. 2 Composition profiles through olivine adjacent to two melt inclusions. Electron microprobe analyses were performed at $15 \mathrm{kV}$, $50 \mathrm{nA}$, using the minimum beam size $(-2-3 \mu \mathrm{m})$ and $2-\mu \mathrm{m}$ step. Counting times were $30 / 15 \mathrm{~s}$. for $\mathrm{Fe}$ (peak/background) and $10 / 5 \mathrm{~s}$. for $\mathrm{Mg}$ and $\mathrm{Si}$. The profiles were symmetrical on both sides of the inclusions (second half is not shown; complete data available from the authors). The boundary between glass and olivine lies between two points that show overlap between these two phases. The phase transition is best seen on the plot with the structural formula units (cations per 4 oxygen). a The profile for a homogenised, partially reequilibrated inclusion $\mathrm{O}-64 \mathrm{a}$ (124 $\mu \mathrm{m}$ in diameter) in sample 16-26-2 from Tongan high-Ca boninites. The grey line on the $\mathrm{FeO}^{\mathrm{t}}$ plot shows

crysts. $\mathrm{FeO}^{\mathrm{t}}$ contents of reheated melt inclusions in olivine phenocrysts $\left(\mathrm{FO}_{87-92}\right)$ from this sample range from 3 to $7 \mathrm{wt} \%$ (Fig. 3c), and are all significantly lower than the whole rock values. As for the Merelava suite, there is a negative correlation between $\mathrm{Fo}$ and the lowest $\mathrm{FeO}^{\mathrm{t}}$ in melt inclusions (Fig. 3d).

\section{Rinjani Volcano, Sunda arc}

The Rinjani suite is an ankaramite-basalt fractionation sequence with a range of $\mathrm{MgO}$ from 8 to $14 \mathrm{wt} \%$ and $\mathrm{FeO}^{\mathrm{t}}$ from 9 to 10 wt\% (Fig. 3e; Foden 1983; Della-Pasqua and

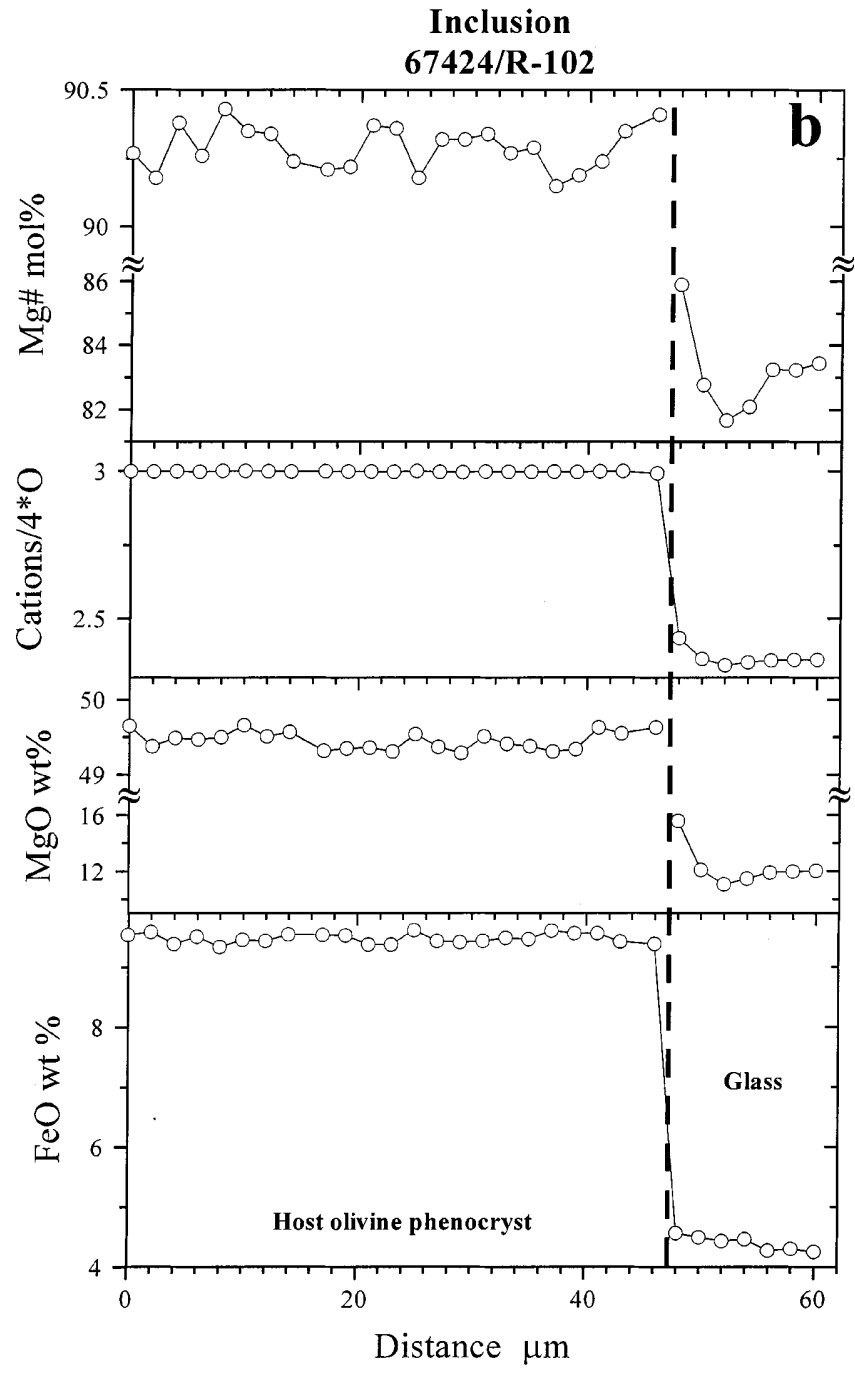

our modelling, which represents the diffusion profile in the host olivine after $20 \%$ re-equilibration. The symmetry of the profile across both sides of the inclusion confirms that the increase in $\mathrm{Fe}$ in olivine adjacent to the melt inclusion is a result of re-equilibration and does not reflect compositional zoning of the phenocryst. The difference between the calculated and observed profile immediately next to the inclusion results from analytical overlap. b The profile for a reheated, completely re-equilibrated inclusion $R-102(50 \mu \mathrm{m}$ in diameter) in sample 67424 from the Ulakan suite. Since this inclusion is completely re-equilibrated, no diffusion profile is observed in the host olivine. See text for discussion and calculation procedures

Varne 1997). The most primitive sample in this suite (sample 48001) has abundant olivine $\left(\mathrm{Fo}_{91-76}\right)$ and clinopyroxene phenocrysts. Reheated melt inclusions in some of the olivines $\left(\mathrm{Fo}_{91-88}\right)$ have $\mathrm{FeO}^{\mathrm{t}}$ contents from 5 to $10 \mathrm{wt} \%$. No correlation between Fo and the lowest $\mathrm{FeO}^{\mathrm{t}}$ in melt inclusions is apparent (Fig. 3f), although this may reflect the narrow Fo range of the olivines studied.

\section{Northern Tonga forearc}

The most primitive sample in this suite (16-26-2, $\sim 28 \mathrm{wt} \% \mathrm{MgO}$, Fig. 1) has olivine $\left(\mathrm{Fo}_{92.2-85}\right)$ but rarely 
Fig. $3 \mathrm{FeO}^{\mathrm{t}}$ contents of melt inclusions (open circles) from four subduction-related suites compared with the $\mathrm{FeO}^{\mathrm{t}}$ contents of rock samples and glasses from these suites (crosses; symbols as in Fig. 1). a, b Merelava Island, Vanuatu arc; c, d Ulakan Formation, Sunda arc; e, f The Rinjani Volcano, Sunda arc; $\mathbf{g}, \mathbf{h}$ Northern Tonga forearc. Fo values plotted in $\mathbf{b}, \mathbf{d}, \mathbf{f}, \mathbf{h}$ were calculated for each whole rock/ glass analysis using the olivine-melt equilibrium model of Ford et al. (1983). See Appendix for the estimations of the oxidation state of $\mathrm{Fe}$ used in our calculations
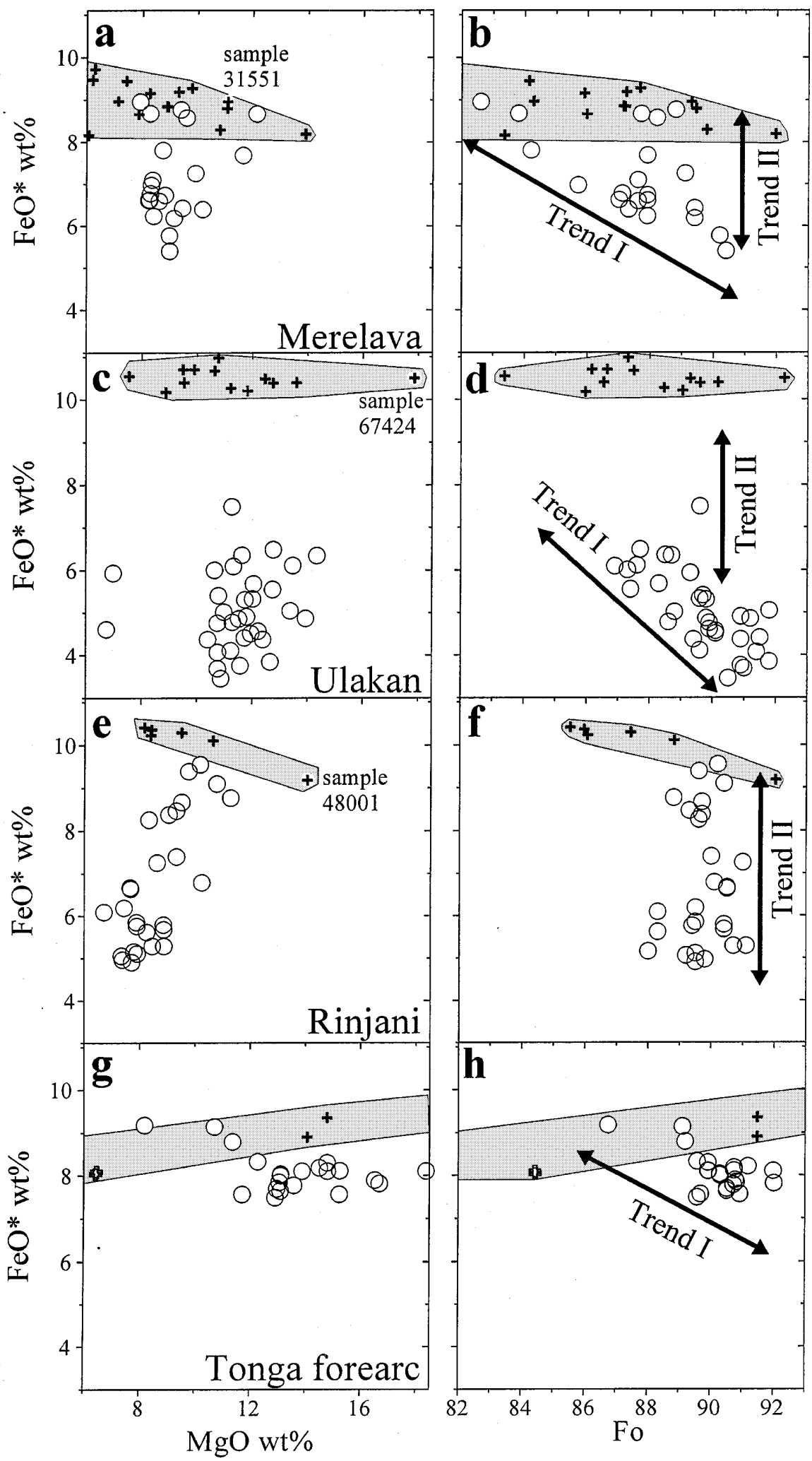

orthopyroxene and clinopyroxene phenocrysts. Homogenised melt inclusion compositions in the olivine phenocrysts $\mathrm{Fo}_{92-86}$ from this sample are shown in Fig. 3g, h. Melt inclusions in high-Fo phenocrysts $\left(\mathrm{Fo}_{>}\right.$89.5) were discussed in the previous section. Although all inclusions in high-Fo phenocrysts have lower $\mathrm{FeO}^{\mathrm{t}}$ contents than those along the wholerock trend, the difference in $\mathrm{FeO}^{\mathrm{t}}$ contents between rocks and these inclusions, and the 
range of inclusion $\mathrm{FeO}^{\mathrm{t}}$ contents at a given $\mathrm{Fo}$, are much smaller than in the three suites discussed above. Also, there is no correlation between $\mathrm{FeO}^{\mathrm{t}}$ and $\mathrm{Fo}$ for most magnesian olivines. However, $\mathrm{FeO}^{\mathrm{t}}$ contents of homogenised inclusions in less magnesian olivines $\left(\mathrm{Fo}_{<89.5}\right)$ are higher than in olivines $\left(\mathrm{Fo}_{>}\right.$89.5), and overlap with those along the whole rock trend (Fig. 3h).

\section{Summary}

In general, $\mathrm{FeO}^{\mathrm{t}}$ contents in melt inclusions vary from those similar to the whole rock trend of a suite to significantly lower values. The extent of Fe-loss clearly varies between different suites, with the largest effect shown by the Ulakan suite, and the smallest by the Tongan boninites.

The lowest $\mathrm{FeO}^{\mathrm{t}}$ contents in melt inclusions occur in the most magnesian olivines and, for a sufficient compositional range of olivine phenocrysts, a negative correlation exists between host $\mathrm{Fo}$ and the lowest $\mathrm{FeO}^{\mathrm{t}}$ in melt inclusions at a given Fo (trend I, Fig. 3b, d, h). At the same time, significant variations in $\mathrm{FeO}^{\mathrm{t}}$ contents at a given Fo are also common (trend II, Fig. 3b, d, f).

In all the suites studied, melt inclusions in a single grain (maximum of seven inclusions in one phenocryst from Rinjani Volcano) show a limited range of $\mathrm{FeO}^{\mathrm{t}}$ contents $(< \pm 0.5 \mathrm{wt} \%)$ regardless of the size of the inclusions (maximum range analysed in one grain $30-70 \mu \mathrm{m}$, the total range of analysed inclusions $20-130 \mu \mathrm{m}$ ).

Table 1 Calculated re-equilibration paths of a melt inclusion trapped by a magnesian olivine phenocryst $\left(\mathrm{Fo}_{93.1}\right)$. All compositions are plotted on Fig. 4 . $A=$ trapped melt compositions; $B, B_{1}$, $\mathrm{B}_{2}=$ melt inclusion compositions at the moment of eruption; $\mathrm{A}_{1}$, $\mathrm{A}_{2}=$ melt inclusion compositions after complete re-melting of olivine crystallised on the walls during cooling; $\mathrm{R}_{1}, \mathrm{R}_{2}=$ melt inclusion compositions after re-equilibration with the host olivine at the temperature of complete re-melting; PRG $=$ the average

\section{The model}

In this section we describe how Fe-loss modifies the original composition of melt inclusions in olivine phenocrysts. For the initially trapped melt composition, a composition (A, Table 1) estimated by Danyushevsky et al. (1995) to be the parental magma for the Western Group of Tongan high-Ca boninites, is chosen.

As described above, cooling after trapping causes crystallisation of the host mineral on the walls of inclusions. When modelling crystallisation processes within melt inclusions in olivine, the oxidation state of Fe in the melt is important. In the calculations presented below, we have assumed that inclusions behave as closed systems for oxygen, and thus $\mathrm{Fe}^{3+}$ behaves as an incompatible element, i.e. its concentration simply increases during crystallisation. An alternative is to assume that the host olivine buffers oxygen fugacity within inclusions causing continuous readjustment of the $\mathrm{Fe}^{2+} /$ $\mathrm{Fe}^{3+}$ ratio during cooling. It is difficult to resolve which mechanism is more appropriate because both lead to similar results. However, the latter causes more significant changes of inclusion compositions in respect of $\mathrm{Fe}$ loss. See Appendix for estimation of the initial $\mathrm{Fe}^{2+} /$ $\mathrm{Fe}^{3+}$ ratio in the trapped melt.

Three re-equilibration cases are described: (1) melt inclusions not affected by re-equilibration, (2) inclusions affected by complete re-equilibration, and (3) inclusions affected by partial re-equilibration.

composition of the pillow-rim glasses of primitive samples from the Western group of Tongan high-Ca boninites; Fo(equil.) = calculated composition of olivine in equilibrium with the melt inside inclusion; Olivine $(\%)=\mathrm{wt}^{\mathrm{O}} \%$ of olivine crystallised on the walls of inclusion during cooling (positive values), and $\mathrm{wt} \%$ of host olivine melted during equilibration of the inclusion with the host at the temperature of homogenisation (negative values); $\mathrm{K}_{\mathrm{D}}$ calculated between host olivine and melt inclusion

\begin{tabular}{|c|c|c|c|c|c|c|c|c|c|}
\hline & \multicolumn{8}{|c|}{ Primitive melt } & \multirow[t]{3}{*}{ PRG } \\
\hline & \multirow{2}{*}{$\begin{array}{l}\text { Trapped } \\
\text { melt } \\
\mathrm{A}\end{array}$} & \multirow{2}{*}{ 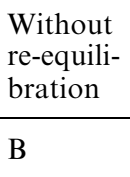 } & \multicolumn{3}{|c|}{$50 \%$ re-equilibration } & \multicolumn{3}{|c|}{$100 \%$ re-equilibration } & \\
\hline & & & $\mathrm{B}_{1}$ & $\mathrm{~A}_{1}$ & $\mathrm{R}_{1}$ & $\mathrm{~B}_{2}$ & $\mathrm{~A}_{2}$ & $\mathrm{R}_{2}$ & \\
\hline $\mathrm{SiO}_{2}$ & 52.57 & 57.55 & 58.81 & 53.15 & 52.36 & 59.59 & 53.52 & 52.17 & 57.92 \\
\hline $\mathrm{TiO}_{2}$ & 0.40 & 0.56 & 0.59 & 0.40 & 0.37 & 0.61 & 0.40 & 0.36 & 0.29 \\
\hline $\mathrm{Al}_{2} \mathrm{O}_{3}$ & 9.51 & 13.51 & 14.15 & 9.63 & 8.97 & 14.55 & 9.70 & 8.62 & 14.17 \\
\hline $\mathrm{Fe}_{2} \mathrm{O}_{3}$ & 0.98 & 1.39 & 1.46 & 0.99 & 0.92 & 1.50 & 1.00 & 0.89 & - \\
\hline $\mathrm{FeO}$ & 7.73 & 6.77 & 4.11 & 5.40 & 8.56 & 2.49 & 3.93 & 9.09 & - \\
\hline $\mathrm{MnO}$ & 0.20 & 0.22 & 0.25 & 0.20 & 0.19 & 0.26 & 0.20 & 0.19 & 0.12 \\
\hline $\mathrm{MgO}$ & 19.01 & 6.47 & 6.47 & 20.50 & 20.89 & 6.39 & 21.44 & 22.08 & 6.44 \\
\hline $\mathrm{CaO}$ & 7.62 & 10.71 & 11.23 & 7.72 & 7.21 & 11.58 & 7.78 & 6.93 & 11.20 \\
\hline $\mathrm{Na}_{2} \mathrm{O}$ & 1.29 & 1.83 & 1.92 & 1.30 & 1.22 & 1.97 & 1.31 & 1.17 & 1.34 \\
\hline $\mathrm{K}_{2} \mathrm{O}$ & 0.59 & 0.84 & 0.88 & 0.60 & 0.56 & 0.91 & 0.61 & 0.54 & 0.40 \\
\hline $\mathrm{P}_{2} \mathrm{O}_{5}$ & 0.10 & 0.14 & 0.15 & 0.10 & 0.09 & 0.15 & 0.10 & 0.09 & 0.03 \\
\hline $\mathrm{Mg \#}$ & 81.4 & 63.0 & 73.7 & 87.1 & 81.3 & 82.0 & 90.7 & 81.2 & - \\
\hline $\mathrm{FeO}^{\mathrm{t}}$ & 8.61 & 8.02 & 5.42 & 6.30 & 9.39 & 3.84 & 4.83 & 9.89 & 8.06 \\
\hline Fo(equil.) & 93.1 & 83.0 & 89.1 & 95.5 & 93.1 & 93.1 & 96.8 & 93.1 & - \\
\hline Olivine $(\%)$ & 0 & 29.6 & 32.0 & 0 & -7.3 & 33.3 & 0 & -12.6 & - \\
\hline $\mathrm{K}_{\mathrm{D}}$ & 0.32 & 0.13 & 0.21 & 0.50 & 0.32 & 0.34 & 0.72 & 0.32 & - \\
\hline
\end{tabular}


Fig. 4a-c Re-equilibration of melt inclusions in olivine phenocrysts. a Re-equilibration paths of a parental melt composition (A, Table 1) of the Western Group of Tongan high-Ca boninites trapped in equilibrium with $\mathrm{Fo}_{93.1}$. Homogenised melt inclusions in high-Fo olivines (open circles) and naturally quenched, unheated melt inclusions in high-Fo olivines (open diamonds) are shown for comparison. Inclusion O-64a shown in Fig. 2a is identified. Shaded field on the $\mathrm{FeO}^{\mathrm{t}}-\mathrm{MgO}$ plot represents the whole rock/glass trend from Fig. 1. Thin dashed lines on the $\mathrm{FeO}-\mathrm{MgO}$ plot represent $\mathrm{FeO} / \mathrm{MgO}$ values of the residual melt within the inclusion in equilibrium with the surrounding olivine rim at the moment of eruption. Cartoons at the bottom of this figure show compositional profiles across the inclusion at $A, B$, and $B_{2}$. All calculations assume the infinitely large size of olivine. That host crystals behave as infinite environments for melt inclusions was demonstrated by Tait (1992). Path $A$ to $B$ reflects the depletion in olivine components due to the crystallisation of a zoned olivine rim on the walls of the inclusion during cooling before eruption. $B$ represents the composition of the inclusion at the moment of eruption, whereas path $B$ to $C$ reflects further compositional change caused by rapid quench growth of olivine during eruption. In a homogenisation experiment path $C-B-A$ is reversed and the original composition of the melt inclusion $A$ at the moment of trapping is restored. If partial re-equilibration $(50 \%)$ with the host occurs during cooling before eruption, then the melt inside the inclusion evolves along path $A-B_{1}-C_{1}$. During a homogenisation experiment path $B_{1}-$ $C_{1}$ is reversed, but with increasing temperature after $B_{1}$, the composition of the melt is driven towards $A_{1}$ instead of $A$. Thus, the homogenised composition of a partially re-equilibrated melt inclusion, $A_{1}$, has lower $\mathrm{FeO}^{\mathrm{t}}$ and higher $\mathrm{Mg} \#$ compared to the original composition $A$. Similarly, if complete re-equilibration occurs (100\%), then the crystallisation path $A-B_{2}$ will not be reversed and the homogenised melt inclusion composition will be $A_{2}$ rather than $A$. Therefore, the compositions of homogenised inclusions affected by reequilibration systematically inherit lower $\mathrm{FeO}^{\mathrm{t}}$ contents and are at chemical disequilibrium (higher $\mathrm{K}_{\mathrm{D}}$ values), with their host olivine. $R_{1}$ and $R_{2}$ correspond to the compositions of inclusions if they are allowed to equilibrate with the host phenocrysts at the temperature of complete homogenisation. A small difference in $\mathrm{Mg} \#$ of the melt inside the inclusion along the $A-B_{2}$ trend ( 81.4 at $A$ vs. 82.0 at $B_{2}$ ) reflects the temperature/compositional dependence of the $\mathrm{K}_{\mathrm{D}}$ built in the model of Ford et al. (1983). See Appendix for calculation details. b Re-equilibration paths of an evolved melt composition $A$ (Table 2) trapped in equilibrium with $\mathrm{Fo}_{89.6}$. Symbols are as in a. Note smaller crystallisation interval before eruption in $\mathbf{b}$, which reduces the maximum possible extent of Fe-loss (smaller difference between compositions $A$ and $A_{2}$ compared with a). c Fe-loss triangle. $A, A_{1}$ and $A_{2}$ correspond to melt inclusion compositions in $\mathrm{Fo}_{89.6}$ and $\mathrm{Fo}_{93.1}$ as shown in $\mathbf{a}$ and $\mathbf{b}$ respectively. Compositions of homogenised melt inclusions affected by complete re-equilibration $\left(A_{2}\right)$ have decreasing $\mathrm{FeO}^{\mathrm{t}}$ contents with increasing $\mathrm{Fo}$ of their host olivine (Trend I) as a result of increasing crystallisation interval. The compositions of homogenised melt inclusions affected by partial re-equilibration $\left(A_{1}\right)$ are intermediate between melt inclusions of compositions $A$ and $A_{2}$. Variable cooling rates generate variable $\mathrm{FeO}^{\mathrm{t}}$ contents in similar forsteritic olivines (Trend II). Inclusion $\mathrm{O}-64 \mathrm{a}$ shown in Fig. 2a is identified

Composition of homogenised melt inclusions not affected by re-equilibration

During fast cooling (for the purpose of this model, fast implies that there is not enough time for re-equilibration to occur via diffusion in the host; see discussion on time constraints below), the trapped melt evolves by fractional crystallisation of the host mineral on the walls of the inclusion. The crystallisation path A of the melt inclusion trapped by olivine $\mathrm{Fo}_{93.1}$ is illustrated in Fig. 4a (see Appendix for details of calculation). The trapped
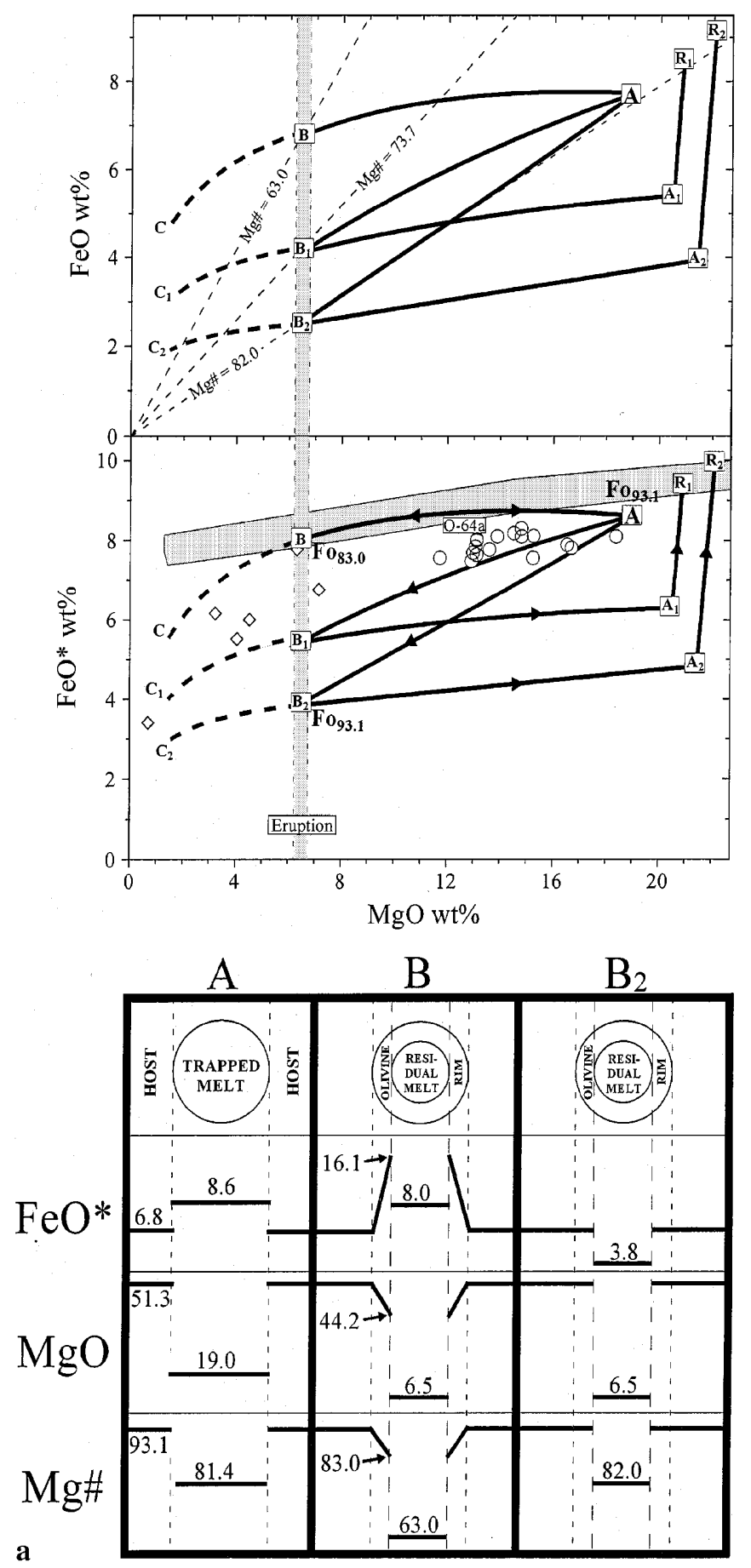

melt composition has $\mathrm{Mg} \# \sim 81.4$ and a $\mathrm{Fe}^{2+} / \mathrm{Fe}^{3+}$ ratio of 8.8. Crystallisation of olivine on the walls of the inclusion before eruption forms a zoned rim that rapidly depletes the residual melt in $\mathrm{MgO}$ towards composition B (Fig. 4a).

During eruption, the residual melt in the magma cools rapidly and forms the groundmass of the rock and, in the case of Tongan high-Ca boninites, pillow-rim glasses. Since the $\mathrm{MgO}$ content of olivine-saturated basaltic liquid is buffered mainly by temperature (e.g. Roeder and Emslie 1970; Ford et al. 1983), the 

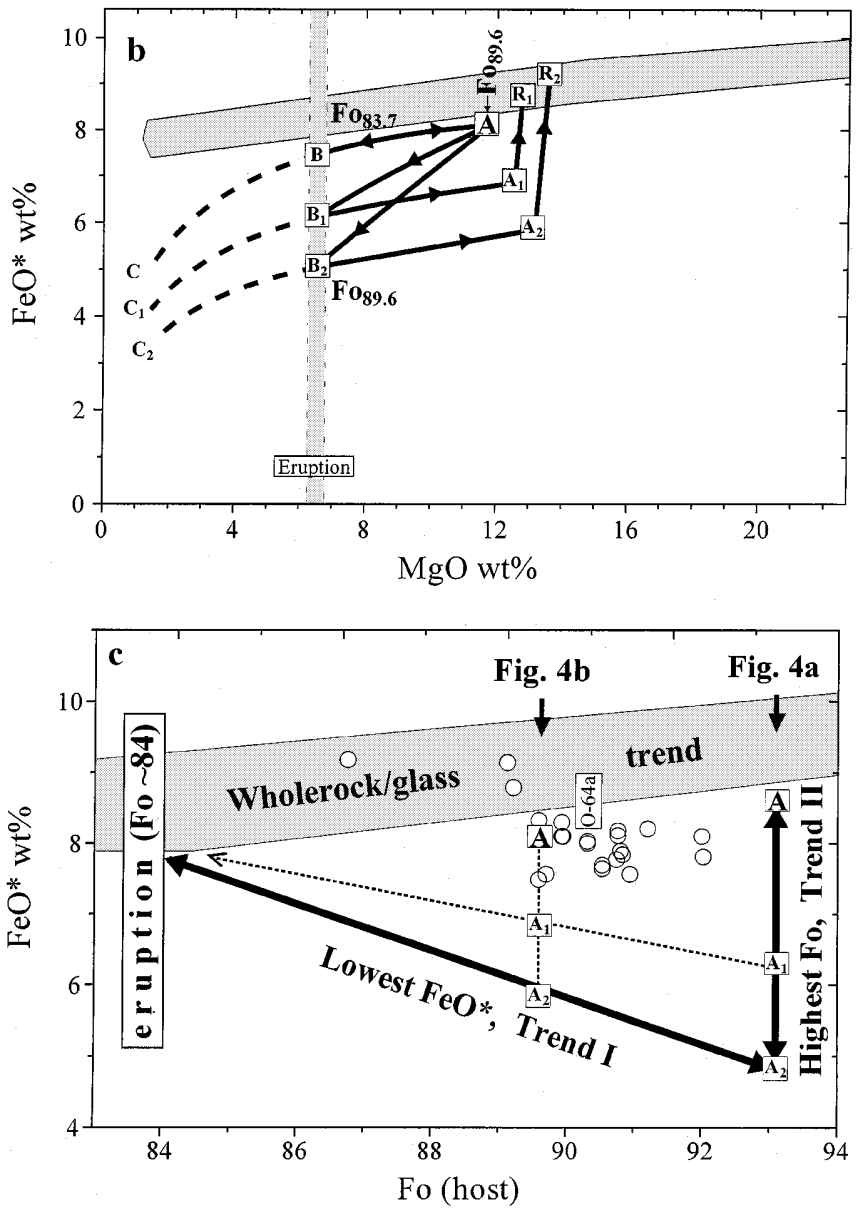

Fig. 4 (Contd.)

$\mathrm{MgO}$ content of the residual melt within the inclusion and the $\mathrm{MgO}$ content of the melt in the magma surrounding the host olivine phenocryst during eruption must be approximately the same. Thus, the groundmass $\mathrm{MgO}$ content should approximate the $\mathrm{MgO}$ content of the residual melt within the inclusion at the moment of eruption.

In our example, the $\mathrm{MgO}$ contents of pillow-rim glasses of the olivine-phyric samples are approximately $6.5 \mathrm{wt} \% \mathrm{MgO}$ (Fig. 1, Table 1). At the moment of eruption, the composition of the residual melt within the inclusion (B, Table 1, Fig. 4a) has Mg\# of $63.0 \%$. The olivine rim on the walls of this inclusion (formed by crystallisation of $29.6 \mathrm{wt} \%$ of olivine from the initially trapped composition) is zoned from $\mathrm{Fo}_{93.1}$ to $\mathrm{Fo}_{83.0}$ (Fig. 4a).

Depending on the efficiency of natural quenching during eruption, the residual melt can be transformed into glass of the same composition (B), or can be further modified by continuing crystallisation of olivine on the walls (path B to C, Fig. 4a). This crystallisation path of the residual melt during quenching is difficult to describe quantitatively because it may not be controlled by equilibrium $\mathrm{K}_{\mathrm{D}}$, and therefore only its approximate position is shown. Compositions of naturally quenched, glassy unheated melt inclusions in high-Fo olivine phenocrysts from the Western Group of Tongan high-Ca boninites are shown in Fig. 4a for comparison.

During a melt inclusion heating experiment, melting of the zoned olivine rim on the walls reverses the composition of the residual melt towards the originally trapped composition along path $\mathrm{C}$ to $\mathrm{B}$, and then to $\mathrm{A}$ (Fig. 4a). Thus, at the moment of homogenisation, the composition of the melt inclusion equals the original composition, A of the trapped melt.

Compositions of homogenised melt inclusions affected by complete re-equilibration

When the average cooling rate after trapping is slow enough to allow re-equilibration of the olivine rim on the walls of the inclusions with the olivine host (see discussion below for time considerations), the olivine rim will not be zoned and its composition will be the same as that of the host (i.e. Fo ${ }_{93.1}$, Fig. 4a). The main effect of this re-equilibration process is on the residual melt inside the inclusion. Diffusion rates in the melt are faster than in the host olivine crystal and therefore, as the olivine rim re-equilibrates, the residual melt is also re-equilibrated. This implies that the $\mathrm{Mg} \#$ of the melt during cooling will remain nearly constant, approximately 81 in our example, to be in equilibrium with the host olivine. As a result, the combined composition of the residual melt + olivine rim within the initial volume of the inclusion has a higher $\mathrm{Mg} \#, \mathrm{MgO}$ and lower $\mathrm{FeO}^{\mathrm{t}}$ contents than the originally trapped composition. Therefore, an inclusion attains chemical equilibrium with the host by diffusion of $\mathrm{Fe}$ from its initial volume into the host, compensated by diffusion of $\mathrm{Mg}$ from the host into the inclusion.

The change in composition of the host olivine caused by this diffusion will be virtually undetectable due to the large crystal volume relative to that of the inclusion. The $\mathrm{MgO}$ gained by the inclusion will reside within the olivine rim, as the $\mathrm{MgO}$ content of the residual melt must decrease during cooling analogous to the fast cooling example. This will also lead to additional olivine crystallisation on the walls at a given $\mathrm{MgO}$ content of the residual melt, compared to the example of fast cooling given.

The resulting fractionation path of the residual melt evolution (A-B ${ }_{2}$, see Appendix for recalculating procedure) is shown in Fig. 4a. At the moment of eruption, i.e. $\sim 6.5 \mathrm{wt} \% \mathrm{MgO}$, the residual melt will contain only $3.8 \mathrm{wt}^{\%} \mathrm{FeO}^{\mathrm{t}}$ (Table 1, Fig. 4a, c, f, $8.0 \mathrm{wt} \% \mathrm{FeO}^{\mathrm{t}}$ in the fast cooling case), and have a similar $\mathrm{Mg \#}$ to the originally trapped melt composition (82.0). The olivine rim on the walls of the inclusions will have a constant composition of $\mathrm{Fo}_{93.1}$. A small difference in $\mathrm{Mg} \#$ of the melt inside the inclusion along the $\mathrm{A}-\mathrm{B}_{2}$ trend $(81.4$ at $\mathrm{A}$ vs. 82.0 at $\mathrm{B}_{2}$ ) reflects the temperature/compositional dependence of the $\mathrm{K}_{\mathrm{D}}$ built into the model of Ford et al. (1983). 
Similar to the fast cooling, if the growth of olivine continues with rapid cooling during eruption, it will drive the composition of the residual melt towards $\mathrm{C}_{2}$. Since the extent of re-equilibration during quenching is negligible, the olivine that crystallised during eruption along the path $\mathrm{C}_{2}-\mathrm{B}_{2}$ does not re-equilibrate and, during a heating experiment, the crystallisation path $\mathrm{C}_{2}-\mathrm{B}_{2}$ is fully reversible. However, because the rim that formed along path $\mathrm{A}-\mathrm{B}_{2}$ re-equilibrated, during further heating after $\mathrm{B}_{2}$, the composition of the melt is not driven towards the initial composition $\mathrm{A}$, but towards $\mathrm{Fo}_{93.1}$ (path $B_{2}-A_{2}$ ), which is the composition of the rim formed along $\mathrm{A}-\mathrm{B}_{2}$. Thus, the crystallisation path $\mathrm{A}-\mathrm{B}_{2}$ will not be reversed and as a result, re-equilibrated melt inclusions will inherit relatively low $\mathrm{FeO}^{\mathrm{t}}$ contents after homogenisation when compared to their original composition. If all of the olivine rim is remelted (composition $\mathrm{A}_{2}$, Table 1, Fig. 4a), the inclusion will have $21.4 \mathrm{wt} \% \mathrm{MgO}, 4.8 \mathrm{wt} \% \mathrm{FeO}^{\mathrm{t}}, \mathrm{Mg} \#$ of 90.7 and will be in equilibrium with olivine $\left(\sim \mathrm{Fo}_{96.8}\right)$. Hence, $\mathrm{K}_{\mathrm{D}}$ values between this melt composition and the host olivine (Fo93.1) will be significantly higher than the accepted values $(0.72$ vs. $0.30 \pm 0.03)$. The temperature of complete homogenisation will also be higher than the actual trapping temperature due to the significant modification of the inclusion composition.

In essence, the difference between the two endmember scenarios of cooling is the difference between fractional crystallisation and equilibrium crystallisation dominated by solid. This difference was first described using ternary phase diagrams with a binary series of solid solutions in the pioneering work of Bowen (1928). The analysis of such diagrams clearly shows that fractional crystallisation results in liquids that are more enriched in the low-temperature component of the solid solution (fayalite in our case) relative to the equilibrium crystallisation. However, quantitative analysis of the degree of re-equilibration for systems with values of solid/liquid $>100$, and their comparison with analysed melt inclusions, are simpler when presented on Harker variation diagrams which we use in this paper.

The difference in composition between the homogenised re-equilibrated inclusion and the initial trapped melt reflects the non-equilibrium nature of rim remelting in the homogenisation experiment. The reason why homogenisation experiments cannot be performed under equilibrium conditions is discussed below. However, if the re-equilibrated inclusion is not quenched after homogenisation but is kept at the temperature of its homogenisation for some time, the inclusion will re-equilibrate with the host by reverse diffusion of $\mathrm{Fe}$ into the inclusion and $\mathrm{Mg}$ into the host (see Appendix for calculation procedure). This will be accompanied by additional melting of some host olivine. The $\mathrm{MgO}$ content of the melt will increase slightly during this process. The resulting composition $\left(\mathrm{R}_{2}\right)$ will have significantly higher $\mathrm{MgO}$ and $\mathrm{FeO}^{\mathrm{t}}$ contents than the originally trapped melt (A) (Table 1).
Compositions of homogenised melt inclusions affected by partial re-equilibration

In the case of intermediate cooling rates, melt inclusions can only partially re-equilibrate. Path $\mathrm{A}-\mathrm{B}_{1}-\mathrm{C}_{1}$ in Fig. $4 \mathrm{a}$ is similar to $\mathrm{A}-\mathrm{B}_{2}-\mathrm{C}_{2}$, but along the former path, re-equilibration of the inclusion is not complete $(50 \%$; see Appendix for recalculation procedure). At $\mathrm{B}_{1}$, the olivine rim is less zoned compared to $\mathrm{B}\left(\mathrm{Fo}_{93.1}-\mathrm{Fo}_{89.1}\right.$ vs. $\mathrm{Fo}_{93.1}-\mathrm{Fo}_{83.0}$ ), and the residual melt has $\mathrm{Mg} \#$ of 73.7 (Table 1). As in the two previous examples, the olivine that crystallises during eruption will drive the residual melt composition towards $\mathrm{C}_{1}$ (Fig. 4a). During a heating experiment, path $\mathrm{C}_{1}-\mathrm{B}_{1}$ is reversed, but melting of the partially re-equilibrated rim formed along $\mathrm{A}-\mathrm{B}_{1}$ drives the melt composition towards $\mathrm{A}_{1}$. If all olivine crystallised on the wall is remelted, the melt inclusion will have $20.5 \mathrm{wt} \% \mathrm{MgO}, 6.3 \mathrm{wt}^{\mathrm{t}} \% \mathrm{FeO}^{\mathrm{t}}, \mathrm{Mg} \#=87.1$ and will be in equilibrium with $\mathrm{Fo}_{95.5}$ (Table 1). Thus, a partially reequilibrated melt inclusion has a moderately lower $\mathrm{FeO}^{\mathrm{t}}$ content. If the inclusion is kept at its temperature of homogenisation after heating, it will equilibrate with the host as described in the previous section. The resulting composition $\mathrm{R}_{1}$ (Fig. 4a, Table 1) will be intermediate between $\mathrm{A}$ and $\mathrm{R}_{2}$.

Compositions of homogenised inclusions in high-Fo olivines from the Western Group of Tongan boninites are shown as open circles in Fig. 4a. It can be clearly seen that the degree of re-equilibration in the case of the Tongan boninites was small, hence the relatively small difference in $\mathrm{FeO}^{\mathrm{t}}$ contents between melt inclusions and the whole rock/glass trend.

Effect of fractionation interval before eruption and the "Fe-loss" triangle

Figure $4 \mathrm{~b}$ shows the evolution of a melt composition trapped by a relatively evolved olivine phenocryst $\left(\mathrm{Fo}_{89.6}\right)$ shortly before eruption. The melt composition \#7 in Table 4 of Sobolev and Danyushevsky (1994) is chosen for the initial trapped composition. The crystallisation paths are shown for cases of no re-equilibration (A-B), and for partial $(50 \%)$ and complete re-equilibration, $\mathrm{A}-\mathrm{B}_{1}$ and $\mathrm{A}-\mathrm{B}_{2}$ respectively (see Table 2 ).

As can be seen in Fig. 4, the extent of the compositional change caused by Fe-loss during complete re-equilibration is dependent on the fractionation (i.e., temperature) interval between trapping and natural quenching. This means that the difference in $\mathrm{FeO}^{\mathrm{t}}$ contents between the initially trapped composition (A) and the homogenised, completely re-equilibrated composition $\left(\mathrm{A}_{2}\right)$, is proportional to the difference in $\mathrm{MgO}$ contents (i.e. degree of fractionation/temperature) between trapping and eruption. Therefore, the maximum Fe-loss that can be experienced by melt inclusions trapped shortly before eruption is significantly less than that for inclusions trapped earlier (compare Fig. 4a, b). This observation implies that if inclusions in all pheno- 
Table 2 Calculated re-equilibration paths of a melt inclusion trapped by an evolved olivine phenocryst $\left(\mathrm{Fo}_{89.6}\right)$. All compositions are plotted in Fig. 4. $A$ Trapped melt compositions; $B, B_{1}, B_{2}$ melt inclusion compositions at the moment of eruption; $A_{1}, A_{2}$ melt inclusion compositions after complete remelting of olivine crystallised on the walls during cooling; $R_{1}, R_{2}$ melt inclusion compositions after re-equilibration with the host olivine at the temperature of complete remelting; $P R G$ the average composition of the pillow- rim glasses of primitive samples from the Western Group of Tongan high-Ca boninites; Fo(equil.) calculated composition of olivine in equilibrium with the melt inside inclusion; Olivine (\%) $\mathrm{wt} \%$ of olivine crystallised on the walls of inclusion during cooling (positive values), and $\mathrm{wt} \%$ of host olivine melted during equilibration of the inclusion with the host at the temperature of homogenisation (negative values); $K_{D}$ calculated between host olivine and melt inclusion

\begin{tabular}{|c|c|c|c|c|c|c|c|c|}
\hline & \multicolumn{8}{|l|}{ Evolved melt } \\
\hline & $\begin{array}{l}\text { Trapped melt } \\
\mathrm{A}\end{array}$ & $\begin{array}{l}\text { Without } \\
\text { re-equilibration } \\
\mathrm{B}\end{array}$ & $\mathrm{B}_{1}$ & $\mathrm{~A}_{1}$ & $\mathrm{R}_{1}$ & $\mathrm{~B}_{2}$ & $\mathrm{~A}_{2}$ & $\mathrm{R}_{2}$ \\
\hline $\mathrm{SiO}_{2}$ & 56.80 & 59.31 & 59.98 & 57.13 & 56.60 & 60.56 & 57.40 & 56.40 \\
\hline $\mathrm{TiO}_{2}$ & 0.48 & 0.55 & 0.56 & 0.48 & 0.46 & 0.57 & 0.48 & 0.45 \\
\hline $\mathrm{FeO}$ & 7.12 & 6.32 & 4.95 & 5.86 & 7.74 & 3.85 & 4.85 & 8.25 \\
\hline $\mathrm{MnO}$ & 0.14 & 0.13 & 0.14 & 0.14 & 0.14 & 0.14 & 0.14 & 0.14 \\
\hline $\mathrm{MgO}$ & 11.76 & 6.46 & 6.50 & 12.55 & 12.77 & 6.44 & 13.17 & 13.60 \\
\hline $\mathrm{CaO}$ & 8.96 & 10.27 & 10.51 & 9.02 & 8.73 & 10.72 & 9.06 & 8.53 \\
\hline $\mathrm{Na}_{2} \mathrm{O}$ & 1.46 & 1.68 & 1.73 & 1.47 & 1.42 & 1.76 & 1.48 & 1.39 \\
\hline $\mathrm{K}_{2} \mathrm{O}$ & 0.69 & 0.80 & 0.81 & 0.70 & 0.67 & 0.83 & 0.70 & 0.66 \\
\hline $\mathrm{K}_{\mathrm{D}}$ & 0.34 & 0.22 & 0.29 & 0.44 & 0.34 & 0.34 & 0.56 & 0.34 \\
\hline
\end{tabular}

crysts from a magmatic suite are re-equilibrated equally, one can expect a negative correlation between the Fo content of the host olivine and $\mathrm{FeO}^{\mathrm{t}}$ content of its homogenised inclusions. We observed this correlation in three suites on Fig. 3b,d,h (trend I). The trend formed by completely re-equilibrated inclusions defines the lowest possible $\mathrm{FeO}^{\mathrm{t}}$ contents in melt inclusions (Fig. 4c). If different crystals of the same composition experience variable degrees of re-equilibration, a range of $\mathrm{FeO}^{\mathrm{t}}$ contents for homogenised inclusions in olivine of a given Fo content can be expected. The range was observed in three suites (trend II, Fig. 3b, d, f). Since the largest range is predicted in the most magnesian olivines, the range of compositions of homogenised melt inclusions for a given suite must lie within a triangle on a $\mathrm{Fo}_{\mathrm{O}} \mathrm{FeO}^{\mathrm{t}}$ diagram which we have called the "Fe-loss" triangle (Fig. 4c). The triangle is defined by trend I, formed by completely re-equilibrated inclusions, and trend II, by variably re-equilibrated inclusions in the most magnesian olivines. It is bounded at the top by the trend of melt evolution during crystallisation in the magma chamber.

\section{Discussion}

"Fe-loss" triangles for the suites studied

This section compares the observed variations in $\mathrm{FeO}^{\mathrm{t}}$ contents of melt inclusions with the range predicted from our model. The Fe-loss triangle for each sample studied can be constructed using: (1) $\mathrm{FeO}^{\mathrm{t}}$ vs. $\mathrm{MgO}$ trend of whole rock/groundmass/glass compositions for the suite (as an approximation for the melt $\mathrm{FeO}^{\mathrm{t}}$ contents during crystallisation); (2) the most magnesian olivine phenocryst in the sample; (3) groundmass composition of the sample (or pillow-rim glass composition), which represents melt composition at the moment of eruption; and (4) the oxidation state of Fe during crystallization (see Appendix for calculation procedure). The main requirement of our model is that no homogenised/ reheated inclusion compositions plot below the lowest $\mathrm{FeO}^{\mathrm{t}}$ trend (Fig. 4c).

As shown in Fig. 4c, and discussed in the previous section, homogenised melt inclusions in olivine phenocrysts from the Western Group of Tongan high-Ca boninites conform to the Fe-loss triangle constructed for this suite. The Fe-loss triangles for the remaining three suites are shown in Fig. 5.

The most magnesian olivine of sample 33551 from the Merelava suite is $\mathrm{Fo}_{90.5}$ (Fig. 5a). The groundmass composition of this sample has approximately $5 \mathrm{wt} \%$ $\mathrm{MgO}$ (Barsdell 1988). The $\mathrm{Fe}^{2+} / \mathrm{Fe}^{3+}$ ratio during crystallisation is estimated at $\sim 7.4$ (Della-Pasqua 1997). Figure 5a shows that the compositions of reheated melt inclusions from this sample lie within the calculated Fe-loss triangle. For a given host olivine composition, the $\mathrm{FeO}^{\mathrm{t}}$ contents of inclusions range from nearly completely re-equilibrated (i.e. close to the lowest $\mathrm{FeO}^{t}$ trend) to unaffected by re-equilibration (i.e. overlap with the whole rock trend). According to the Fe-loss model presented here, these variations in $\mathrm{FeO}^{\mathrm{t}}$ indicate that the melt inclusions experienced variable degrees of re- 


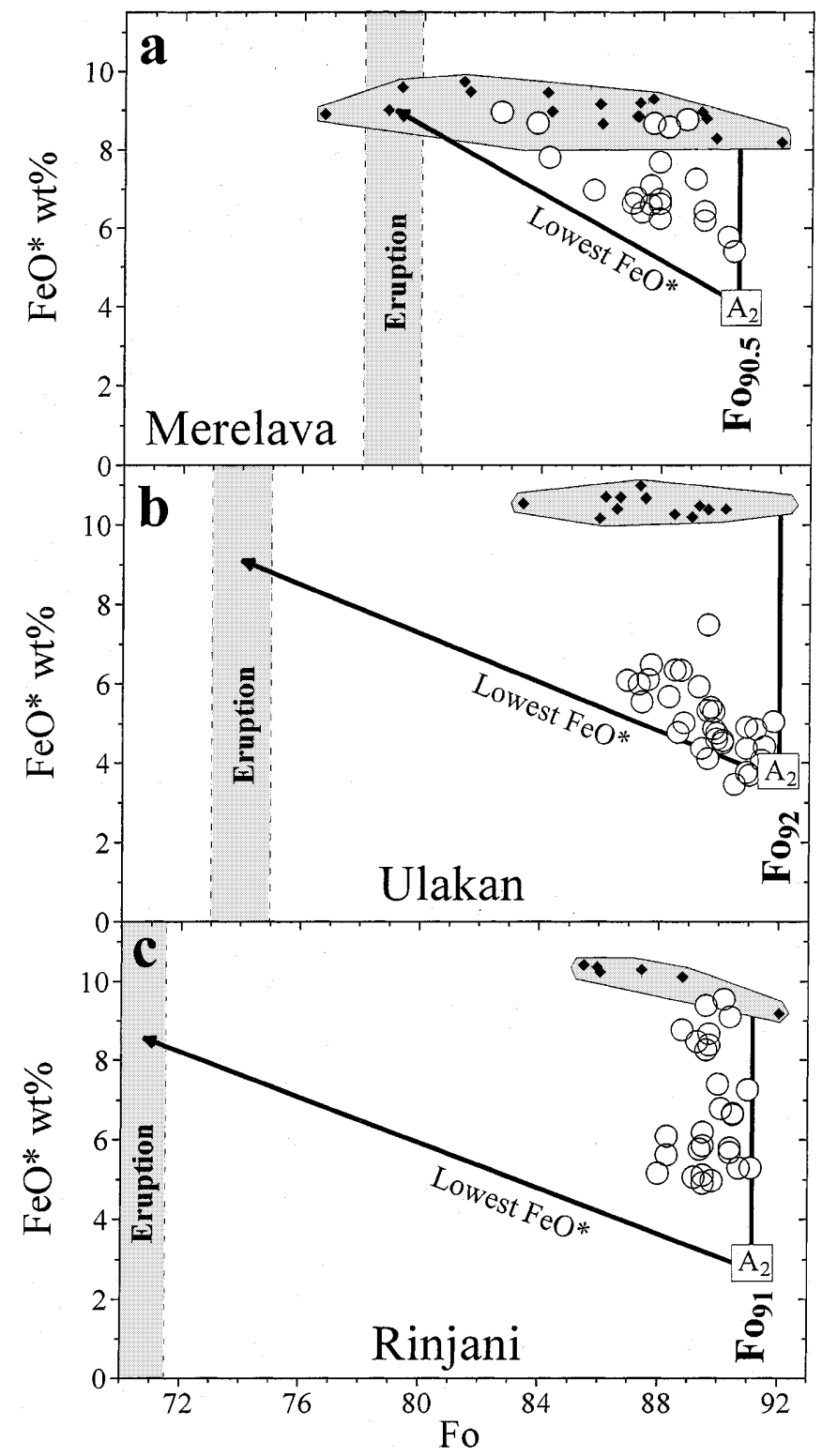

Fig. 5 Fe-loss triangles for three subduction-related suites. Symbols are as in Fig. 3. Fo values were calculated for each whole rock analysis using olivine-melt equilibrium model of Ford et al. (1983). The Fe-loss triangle for each suite is defined using the calculated compositions of completely re-equilibrated homogenised inclusions in the most magnesian olivines $\left(A_{2}\right)$. See text for discussion and Appendix for the estimations of the oxidation state of $\mathrm{Fe}$ used in calculations

equilibration throughout the crystallisation history of the host magma.

The highest Fo olivine in the most magnesian sample of the Ulakan suite (sample 67424) is $\mathrm{Fo}_{92}$ (Fig. 5b). The groundmass composition of this sample has $\sim 4 \mathrm{wt} \%$ $\mathrm{MgO}$ (Della-Pasqua 1997). The $\mathrm{Fe}^{2+} / \mathrm{Fe}^{3+}$ value during crystallisation is estimated at $\sim 5.6$ (Della-Pasqua and Varne 1997). The compositions of reheated melt inclusions from this sample also lie within the Fe-loss triangle. Most of these compositions overlap with the lowest $\mathrm{FeO}^{\mathrm{t}}$ trend, indicating that their compositions have been completely re-equilibrated with host olivines prior to eruption. Notably, the composition of one inclusion in $\mathrm{Fo}_{89.5}$, with relatively higher $\mathrm{FeO}^{\mathrm{t}}$, indicates that partial re-equilibration has also rarely occurred.

The most magnesian olivine of sample 48001 from the Rinjani suite is $\mathrm{Fo}_{91}$ (Fig. 5c). The $\mathrm{Fe}^{2+} / \mathrm{Fe}^{3+}$ value during crystallisation is estimated at about 3.7 , and the groundmass composition has $\sim 2.5 \mathrm{wt} \% \mathrm{MgO}$ (DellaPasqua 1997). Again, all melt inclusions lie within the constructed Fe-loss triangle. Unlike the two previous examples, most reheated melt inclusions from Rinjani show variable re-equilibration over a narrow range of host olivine compositions. The $\mathrm{FeO}^{\mathrm{t}}$ contents of reheated melt inclusions in $\mathrm{Fo}_{89-90}$ vary from about $5 \mathrm{wt} \%$ (in nearly completely re-equilibrated inclusions) to approximately $9 \mathrm{wt} \%$ (in melt inclusions unaffected by re-equilibration).

Melt inclusions in olivine from subduction-related suites with anomalous low $\mathrm{FeO}^{\mathrm{t}}$ contents were also described by Sobolev et al. (1993), Kamenetsky et al. (1995a, b), Portnyagin et al. (1997) and Kamenetsky et al. (1997). Information presented in these papers is not sufficient to construct the $\mathrm{Fe}$-loss triangles with confidence. However, the degree of re-equilibration recorded by these inclusions is less extreme than in the case of the Ulakan suite (Fig. 5b) and thus we are confident that these inclusions can be explained by our model.

Time constraints on re-equilibration.

The time necessary for the re-equilibration process to occur via inter-diffusion of $\mathrm{Fe}$ and $\mathrm{Mg}$ in olivine is estimated below using the slowest possible scenario. Consider a case where an inclusion is first rapidly cooled (path A-B, Fig. 4a). The compositional profile across such an inclusion is shown on cartoon B (Fig. 4a). If this inclusion is kept at low temperature, it will re-equilibrate with the host via diffusion (path $\mathrm{B}-\mathrm{B}_{2}$, Fig. 4a). The resulting compositional profile across the inclusion is shown on cartoon $\mathrm{B}_{2}$ (Fig. 4a). The equilibration process in this scenario will take longer than along path $\mathrm{A}$ $\mathrm{B}_{2}$, because in the latter case equilibration occurs at higher temperatures.

The re-equilibration time was estimated using the diffusion equation. If we assume that the diffusion process is homogeneous, the appropriate equation for radial diffusion in spherical coordinates is given as:

$\frac{\partial C}{\partial t}=D\left(\frac{\partial^{2} C}{\partial r^{2}}+\frac{2}{r} \frac{\partial C}{\partial r}\right)$

where $C$ is concentration, $D$ is a diffusion coefficient, $r$ is a radial distance from the center of the inclusion, and $t$ is time.

Equation (1) is subject to the Neumann boundary condition at the remote distance $R$ :

$\left.\frac{\partial C}{\partial r}\right|_{r=R}=0$

and to the Dirichlet condition at the interface $r_{0}$ between the residual melt and olivine rim: 
$\left.C(t)\right|_{r=r_{0}}=f\left(C_{\text {melt }(t)}\right)$

Olivine composition in the rim at $r_{0}$ is determined as a function of the residual melt composition $C_{\text {melt(t) }}$ using the model of Ford et al. (1983). The concentration gradient at the interface $r_{0}$ determines the flux of $\mathrm{FeO}^{\mathrm{t}}$ from the inclusion to the host

$D=\left.\frac{\partial C}{\partial r}\right|_{r=r_{0}}$

thus the residual melt concentration $C_{\text {melt }(t)}$ is subject to the constraint that at each time step the total $\mathrm{FeO}^{\mathrm{t}}$ content in $0 \leq r \leq R$ is conserved:

$\iiint_{V} \rho(r) C(r) \mathrm{d} V=$ const

In all our calculations the boundary at distance $R$ was placed at $200 \mu \mathrm{m}$ from the interface $r=r_{0}$. The initial $\mathrm{FeO}$ concentration profile for the problem (1)-(4) is shown in cartoon B of Fig. 4a.

The initial thickness of the rim for a chosen inclusion size can be calculated from Table 1 using the amount of olivine crystallised on the walls. In all our calculations we ignored differences in densities between melt compositions $\mathrm{A}, \mathrm{B}$ and $\mathrm{B}_{2}$ (Table 1) and assumed an average value of $2.65 \mathrm{~g} / \mathrm{cm}^{3}$ (Lange and Carmichael 1987). We also assumed the density of host olivine at magmatic temperatures to be $3.1 \mathrm{~g} / \mathrm{cm}^{3}$ (Niu and Batiza 1991) and ignored changes in density between olivine compositions over the range $\mathrm{Fo}_{85-93}$. We also ignored the difference in the thickness of the olivine rim on the walls, which should change (increase) slightly as a result of re-equilibration. We assumed that re-equilibration occurred at $1100{ }^{\circ} \mathrm{C}$, for which $\mathrm{D}$ for $\mathrm{Fe}-\mathrm{Mg}$ interdiffusion in highmagnesian olivines is $10^{-16.5} \mathrm{~m}^{2} / \mathrm{s}$ (Chakraborty 1997).

Results for three different inclusion sizes are shown on Fig. 6. The times for near complete re-equilibration $(>98 \%)$ vary from $\sim 1$ month to 2 years. This implies that if host phenocrysts spend a longer time in the magma chamber at temperatures lower than their crystallisation temperature, melt inclusions in them must be completely re-equilibrated. Implications of the common presence of partially re-equilibrated inclusions in subduction-related magmatic suites will be discussed elsewhere.

A compositional profile through olivine adjacent to a homogenised partially re-equilibrated inclusion $\mathrm{O}-64 \mathrm{a}$ (radius $62 \mu \mathrm{m}$ ) from Tongan boninites is shown in Fig. 2a (olivine rim was remelted during homogenisation experiment). The increasing $\mathrm{FeO}^{\mathrm{t}}$ content of the host olivine near the inclusion represents a diffusion profile which reflects the re-equilibration process described above. Note also the symmetrical decrease in $\mathrm{MgO}$ of the host olivine, a necessary feature of the Fe-Mg interdiffusion. The re-equilibration process was interrupted by eruption, and this profile was frozen. We modelled this diffusion assuming a two-stage process described above; first, fast cooling that produces a zoned olivine rim on the walls and, secondly, diffusion at a constant temperature. The thick grey line in Fig. 2a shows our results and

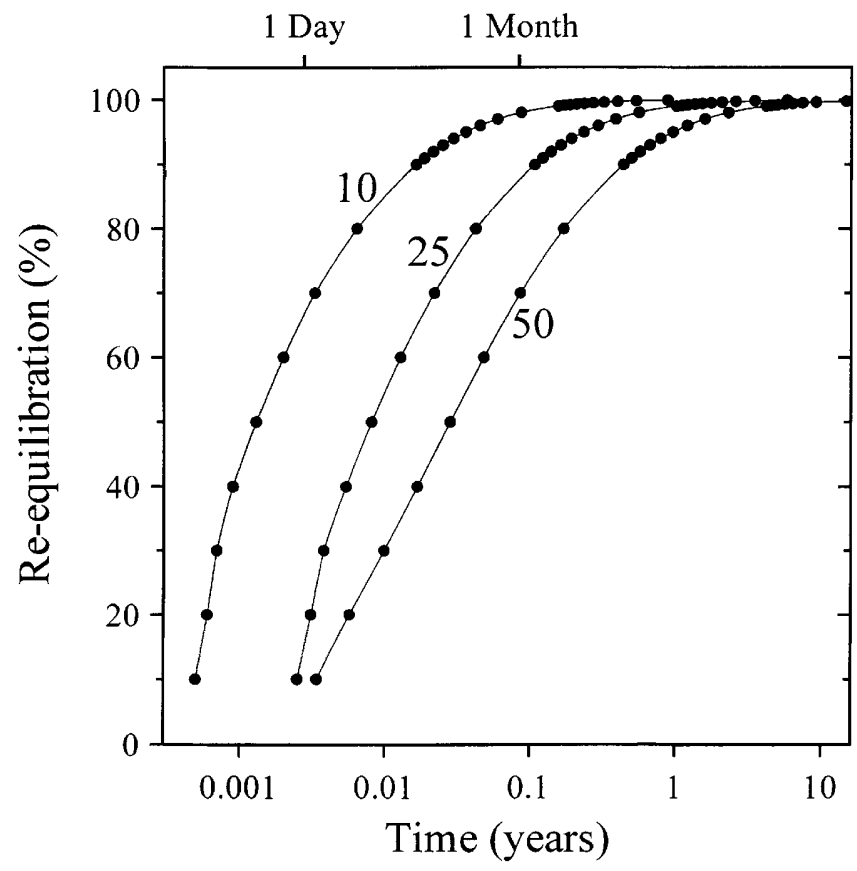

Fig. 6 The effect of inclusion size on re-equilibration time. Numbers next to each curve represent inclusion radius in microns. Percentage of re-equilibration is defined as the amount of $\mathrm{Fe}$ diffused from the inclusions relative to the amount that diffuses when re-equilibration is completed. See text for calculation details

represents the diffusion profile in the host olivine after $20 \%$ re-equilibration. At $1100{ }^{\circ} \mathrm{C}$, this profile is formed in $\sim 17$ days. The difference between the calculated and observed profiles immediately next to the inclusion results from the analytical overlap, as inferred from the stoichiometry (cations per four oxygen).

Figure $2 \mathrm{~b}$ shows a compositional profile through olivine adjacent to a reheated, completely re-equilibrated inclusion $R-102$ (radius $25 \mu \mathrm{m}$ ) from the Ulakan suite. Since the re-equilibration process was complete in this case, no diffusion profile is observed in the surrounding host olivine.

Implications of "Fe-loss" for the accuracy of melt inclusion homogenisation experiments

When re-equilibration occurs, the composition of the inclusion does not evolve towards the trapped composition during heating experiments. Lower Fe and higher $\mathrm{Mg}$ contents of the re-equilibrated inclusions should result in lower density of the melt inside inclusions. Consequently, a higher pressure inside inclusions at a given amount of the remaining rim on the walls would occur. This, in turn, should cause homogenisation (disappearance of the fluid bubble) before all olivine rim is remelted.

However, our data suggest that the effect of density change is negligible, and the amount of olivine that must be melted back to achieve homogenisation approximates the amount of olivine that crystallised on the walls during 
natural cooling and re-equilibration. Thus, due to the higher $\mathrm{MgO}$ contents of the re-equilibrated inclusions (compositions $\mathrm{A}_{1}$ and $\mathrm{A}_{2}$, Fig. 4), homogenisation will occur at temperatures higher than that of trapping. This has been demonstrated by Sobolev and Slutskiy (1984) for the Siberian meimechites. In their study, inclusions quenched after relatively short homogenisation experiments have low $\mathrm{FeO}^{\mathrm{t}}$ contents and high $\mathrm{K}_{\mathrm{D}}$, indicating disequilibrium between homogenised inclusion compositions and the hosts (cf. compositions $\mathrm{A}_{1}$ or $\mathrm{A}_{2}$, Fig. 4). When inclusions were kept at a high temperature for some time, to allow their equilibration with the host (during this process the composition of an inclusion will evolve along a path parallel to the path A-R, Fig. 4), homogenisation occurred at a lower temperature. The homogenised melt had a higher $\mathrm{FeO}^{\mathrm{t}}$ content which yielded an equilibrium $\mathrm{K}_{\mathrm{D}}$ value.

In experimental studies of melt inclusions in olivine phenocrysts from subduction-related magmas, Fe-loss cannot be reversed experimentally because inclusions cannot be kept at a high temperature for long time intervals. As discussed above, diffusion of $\mathrm{H}_{2}$ from inclusions dramatically increases homogenisation temperatures. Experimental procedures and potential difficulties during homogenisation experiments with phenocrysts from $\mathrm{H}_{2} \mathrm{O}$-bearing magmas are described in detail by Danyushevsky et al. (1992) and Sobolev and Danyushevsky (1994, cf. Appendix). A computer program that reconstructs the original composition of homogenised and reheated melt inclusions by reversing the effect of Fe-loss is available from the authors. For homogenised melt inclusions, the calculation is performed assuming that at the moment of homogenisation all olivine that crystallised on the walls is remelted. $\mathrm{Mg}$ is substituted with $\mathrm{Fe}$ in the melt inclusion composition until it is in equilibrium with the host. This calculation provides corrected homogenisation temperature. For reheated melt inclusions, the calculation requires an independent estimate of the trapped melt $\mathrm{FeO}^{\mathrm{t}}$ content and provides the corrected melt composition and trapping temperature.

Implications of Fe-loss for determining the parental melt compositions

from naturally quenched melt inclusions

Compositions of glassy (unheated, naturally quenched) melt inclusions in magnesian olivine phenocrysts are a tempting starting point for estimations of parental melt compositions (e.g. Falloon and Green 1986). As discussed in the previous sections, such inclusions are only affected by crystallisation of the host olivine on the walls of the inclusions and escape complex crystallisation histories of erupted lavas. However, if melt inclusions are affected by Fe-loss, and this is not taken into account, the calculated parental composition will have a lower $\mathrm{MgO}$ content than the true parent.

In case of the Eastern Group of high-Ca boninites (Fig. 7), detailed mineralogical and melt inclusion

Fig. $7 \mathrm{FeO}^{\mathrm{t}}$ vs. $\mathrm{MgO}$ contents of the Eastern Group of Tongan high Ca-boninites and naturally quenched glassy inclusions in olivine phenocrysts $\left(\mathrm{Fo}_{94}\right)$ from sample \#5-25 of this suite. Dotted line indicates groundmass $\mathrm{MgO}$ content of sample \#5-25. Dashed line indicates the position of melts in equilibrium with $\mathrm{Fo}_{94}$. Filled star represents the parental melt composition for the Eastern Group of Tongan boninites (Danyushevsky et al. 1995). Arrow indicates the olivine addition trend used by Falloon and Green (1986) to reconstruct the parental melt composition from the composition of a glassy melt inclusion affected by Fe-loss. This trend was calculated by back-tracking the effect of olivine fractionation on the walls of inclusions. The procedure involves incremental addition of equilibrium olivine to the composition of the melt inclusion until the equilibrium $\mathrm{K}_{\mathrm{D}}$ was attained (see Falloon and Green 1986 for calculation details). Note low $\mathrm{FeO}^{\mathrm{t}}$ and $\mathrm{MgO}$ contents of the parental melt composition estimated by Falloon and Green (1986). See text for discussion

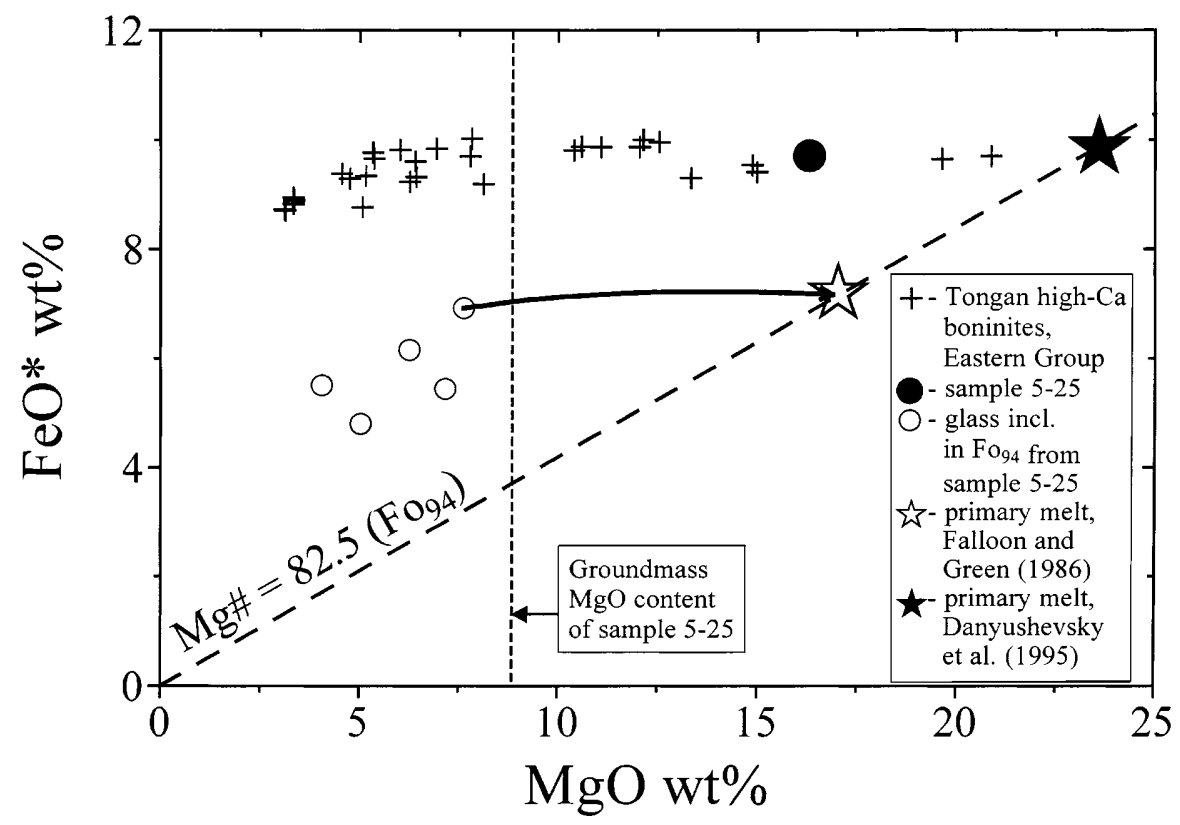


studies (Sobolev and Danyushevsky 1994; Danyushevsky et al. 1995; Danyushevsky, unpublished) have demonstrated that compositions of melt inclusions in $\mathrm{Fo}_{94}$ used by Falloon and Green (1986) have suffered Fe-loss. These studies also show that the parental melt composition for this suite had approximately $24 \mathrm{wt} \%$ $\mathrm{MgO}$ (cf. $\sim 17 \mathrm{wt} \% \mathrm{MgO}$ estimated by Falloon and Green 1986, Fig. 7).

\section{Conclusions}

The compositions of olivine-hosted melt inclusions is likely to have been modified by re-equilibration during natural pre-eruptive cooling of the magma, due to diffusive exchange between the residual melt within inclusions and the host. This process, referred to as Fe-loss, results in decreasing $\mathrm{FeO}^{\mathrm{t}}$ and increasing $\mathrm{MgO}$ contents within the initially trapped volume of the inclusion.

The compositions of homogenised melt inclusions in olivine phenocrysts from four subduction-related suites demonstrate (1) that $\mathrm{Fe}$-loss is a common process in these magmas, (2) that the maximum observed degree of re-equilibration varies between suites, and (3) that within a single sample, variable degrees of re-equilibration can be recorded by melt inclusions that are trapped in olivine phenocrysts with similar Fo contents.

Our modelling demonstrates that re-equilibration is fast. In the largest inclusions in the most magnesian phenocrysts, it is completed within 2 years. When the compositions of parental subduction-related magmas are estimated from naturally quenched, glassy melt inclusions in magnesian olivine phenocrysts, the possibility of Fe-loss must be carefully considered and assessed. Compositions calculated from glassy inclusions affected by $\mathrm{Fe}$-loss will inherit not only erroneously low $\mathrm{FeO}^{\mathrm{t}}$ contents, but also low $\mathrm{MgO}$, due to the inherited higher $\mathrm{Mg} \#$ of the residual melt in re-equilibrated inclusions.

Due to the higher $\mathrm{MgO}$ contents of homogenised melt inclusions affected by Fe-loss, homogenisation temperatures achieved in the heating experiments will be higher than the original trapping temperatures. The extent of overheating will increase depending on the degree of reequilibration, and can reach up to $50{ }^{\circ} \mathrm{C}$ in cases where complete re-equilibration occurs over a cooling interval of $200{ }^{\circ} \mathrm{C}$. Since the effect of $\mathrm{Fe}$-loss in melt inclusions of olivine phenocrysts from subduction-related magmas cannot be reversed experimentally, a computer program has been developed that reconstructs the original composition of re-equilibrated melt inclusions. This program is available from the authors upon request.

Acknowledgments LVD offers special thanks to Alex Sobolev who introduced him to the realm of melt inclusions. FNDP is grateful to R. Varne for critically questioning the "Fe-loss" phenomenon and for generating constructive discussions. We also thank Trevor Falloon and Tony Crawford for numerous stimulating discussions. Formal reviews by Jim Van Orman and Tom Sisson and editorial comments of T.L. Grove have significantly improved the original manuscript. This research was supported by the Australian
Research Council through Large Grants to LVD and R. Varne, and Postdoctoral Fellowship to LVD, by an Australian Postgraduate Research Award and a Writing-Up Scholarship from the University of Tasmania to FNDP.

\section{Appendix: Modelling of olivine crystallisation within inclusions}

Estimation of the oxidation state of $\mathrm{Fe}$ in the melt

Modelling of olivine-melt equilibrium requires information on the $\mathrm{Fe}^{2+} / \mathrm{Fe}^{3+}$ value in the melt. As demonstrated by Danyushevsky and Sobolev (1996), it can be retrieved from the compositions of spinel inclusions in olivine phenocrysts and can be described as a function of the composition of liquidus olivine. During calculations of equilibrium Fo for whole rock and pillow-rim glass analyses (Figs. 3h, 4c), $\mathrm{Fe}^{2+} / \mathrm{Fe}^{3+}$ ratios were calculated after Sobolev and Danyushevsky (1994) as:

$\left(\mathrm{Fe}^{2+} / \mathrm{Fe}^{3+}\right)_{\text {melt }}=0.436 * \mathrm{Fo}-31.8$

During calculations of the inclusion evolution trends shown in Fig. 4 and Table $1, \mathrm{Fe}^{2+} / \mathrm{Fe}^{3+}$ values at trapping were calculated using Eq. (A1). After trapping, $\mathrm{Fe}^{3+}$ was assumed to behave as an incompatible element (inclusions were modelled as closed systems). During calculations of the inclusion evolution trends for the Indonesian and Vanuatu suites (Fig. 5), $\mathrm{Fe}^{2+} / \mathrm{Fe}^{3+}$ values were assumed to be constant (inclusions were modelled as open systems, i.e. the host olivine controls the oxidation state within inclusions). Using spinel inclusions in olivine phenocrysts, $\mathrm{Fe}^{2+} / \mathrm{Fe}^{3+}$ values were estimated to be 7.4 for the Merelava suite, 5.6 for the Ulakan suite, and 3.7 for the Rinjani suite. The same $\mathrm{Fe}^{2+} / \mathrm{Fe}^{3+}$ values were used for calculations of equilibrium Fo for whole rock analyses of these suites (Figs. 3b, d, f, 5).2

Modelling of olivine crystallisation and its reverse

Olivine crystallisation was modelled in steps. At each step the following two conditions had to be met: (1) for each element,

$(\mathrm{wt} \% \text { in Melt })_{\mathrm{old}}=(\mathrm{wt} \% \text { in Melt })_{\text {new }} *(1-\mathrm{X})$

$$
+(\mathrm{wt} \% \text { in Olivine })_{\text {new }} * \mathrm{X}
$$

where $\mathrm{X}$ is the degree of fractionation at each step (calculation step), usually taken as $0.0001(0.01 \%)$, and (2) (Melt) new is in equilibrium with (Olivine) $)_{\text {new }}$ according to the olivine-melt model of Ford et al. (1983). This model allows calculation of olivine composition and liquidus temperature if melt composition is known.

At each step, the above set of equations was solved using an iterative procedure. First, olivine composition was calculated from (Melt) old using the model of Ford et al. (1983), and then (Melt) new was calculated from (1). The olivine composition was calculated again, now from (Melt) new, and a new (Melt) new composition was calculated from (1). This stepwise calculation continues until the difference in calculated olivine compositions was $<0.000001 \mathrm{~mol} \%$ Fo. The melt $\mathrm{Fe}^{2+} / \mathrm{Fe}^{3+}$ values is adjusted at each step.

For calculating the reverse of olivine crystallisation, the above set of equations is converted to:

$$
\begin{aligned}
(\mathrm{wt} \% \text { in Melt })_{\text {new }}= & (\mathrm{wt} \% \text { in Melt })_{\text {old }} *(1-\mathrm{X}) \\
& +(\mathrm{wt} \% \text { in Olivine })_{\text {new }} * \mathrm{X}
\end{aligned}
$$

and, (Melt) $)_{\text {old }}$ is in equilibrium with (Olivine) $)_{\text {new }}$.

No iterative procedure is necessary for this calculation. Using the same value of X, olivine crystallisation can be reversed exactly, step by step. 
Modelling of crystallisation and re-equilibration within melt inclusions in olivine phenocrysts

Crystallisation of olivine on the walls without re-equilibration (path A-B, Fig. 4a, b) was calculated using the procedure described in the previous section. The $\mathrm{Fe}^{2+} / \mathrm{Fe}^{3+}$ value at trapping was calculated using equation (A1) and after that $\mathrm{Fe}^{3+}$ was modelled as an incompatible element. A single step in this calculation consists of subtraction of olivine from the melt and calculation of the new melt composition, hereafter called P1 (Fig. 8).

Modelling of crystallisation of olivine on the walls with complete re-equilibration (path $\mathrm{A}-\mathrm{B}_{2}$, Fig. $4 \mathrm{a}, \mathrm{b}$ ) is schematically shown in Fig. 8. The calculation involves a combination of two steps that is repeated until the residual melt inside the inclusion reaches a chosen $\mathrm{MgO}$ content. The first step in each combination is $\mathrm{P} 1$ which models olivine crystallisation due to a decrease in temperature. After $\mathrm{P1}$, (Melt) new $_{\text {has }}$ lower $\mathrm{MgO}$ and $\mathrm{Mg} \#$ than (Melt) $)_{\text {old }}$ and thus (Olivine) $)_{\text {new }}$ is less magnesian than olivine in

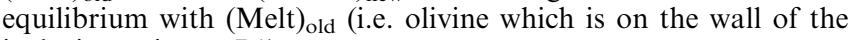
inclusion prior to $\mathrm{P} 1)$.

The second step (which hereafter, will be called P2) models reequilibration of the inclusion with its host after $\mathrm{P} 1$ at constant temperature (Fig. 8). Step P2 is itself complex, being a repeating combination of two steps. The first step describes exchange in $\mathrm{Fe}^{2+}$ and $\mathrm{Mg}$ between the residual melt and olivine on the walls. This is represented by:

$\left(\mathrm{Fe}^{2+}\right)_{\text {melt, new }}=\left(\mathrm{Fe}^{2+}\right)_{\text {melt, old }}-\mathrm{X} 1$

and

$(\mathrm{Mg})_{\text {melt,new }}=(\mathrm{Mg})_{\text {melt,old }}+\mathrm{X} 1$

where $\mathrm{X} 1$ is the calculation step $=1 / 128 * \mathrm{X}$, the calculation step during P1.

This step will be called P3. After P3, the residual melt has higher $\mathrm{MgO}$, and therefore, higher olivine liquidus temperature. This is corrected during the second step (P1a) within P2, which models olivine crystallisation until the liquidus temperature is equal to that after $\mathrm{P} 1$. The $\mathrm{P} 1$ a is identical to $\mathrm{P} 1$, but the calculation step is $1 / 512$ of the step for P1. The combination P3 + P1a (i.e. step P2) is repeated until the residual melt is in equilibrium with the host olivine. After P2, olivine added to the wall during P1 is converted to the composition of the wall prior to P1 (i.e. host olivine composition) and the melt composition is consequently readjusted. To enable modelling of the homogenisation experiment, the amount of olivine that crystallises during each combination of $\mathrm{P} 1+\mathrm{P} 2$ is recorded during calculations.

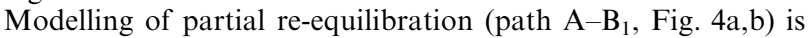
identical to modelling of the complete re-equilibration. The only difference is that step P2 is shorter and continues until melt is in

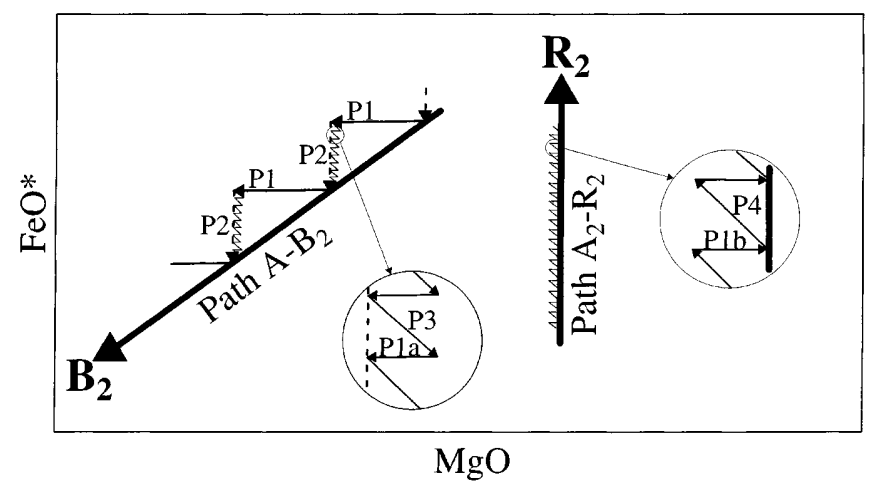

Fig. 8 Schematic cartoon showing calculation steps during modelling of olivine crystallisation and re-equilibration within melt inclusions. See Appendix for detailed explanation equilibrium with (A6) instead of when the residual melt is in equilibrium with the host olivine.

$\mathrm{Fo}_{\text {rim }}=\mathrm{Fo}_{2}+\left(\mathrm{Fo}_{1}-\mathrm{Fo}_{2}\right) *(\mathrm{Y} / 100)$

where $\mathrm{Fo}_{1}$ is olivine in equilibrium with (Melt) $)_{\text {old }}$, i.e. prior to $\mathrm{P} 1$; $\mathrm{Fo}_{2}$ is (Olivine) $)_{\text {new }}$, i.e. olivine in equilibrium with (Melt) new $_{\text {after }}$ $\mathrm{P} 1 ; \mathrm{Y}$ is degree of re-equilibration in percent.

To enable modelling of the homogenisation experiment, the composition of the rim formed at each step $\left(\mathrm{Fo}_{\text {rim }}\right)$ is recorded during calculation (in addition to the amount of olivine crystallised at the step).

Modelling of the homogenisation experiments (paths $B_{2}-A_{2}$ and $\mathrm{B}_{1}-\mathrm{A}_{1}$, Fig. $4 \mathrm{a}, \mathrm{b}$ ) involves step-by-step addition of olivine from the walls to the residual melt. The calculation is continued until all olivine is removed from the walls.

Modelling of inclusion re-equilibration with the host at the temperature of homogenisation after the homogenisation experiment (paths $A_{2}-R_{2}, A_{1}-R_{1}$, Fig. 4a, b) is schematically shown in Fig. 8. The calculation involves a combination of two steps that is repeated until melt inside the inclusion is in equilibrium with the host olivine. The first step, P4, is exactly opposite of step P3:

$\left(\mathrm{Fe}^{2+}\right)_{\text {melt, new }}=\left(\mathrm{Fe}^{2+}\right)_{\text {melt, old }}+\mathrm{X} 1$

and

$(\mathrm{Mg})_{\text {melt, new }}=(\mathrm{Mg})_{\text {melt,old }}-\mathrm{X} 1$

After $\mathrm{P} 4$, the residual melt has lower $\mathrm{MgO}$, and thus lower olivine liquidus temperature. This is corrected during step P1b, which models melting of the host olivine (i.e. addition of olivine components to the melt composition) until liquidus temperature of the melt is equal to that at homogenisation (i.e. before P4). Step $\mathrm{P} 1 \mathrm{~b}$ is similar to modelling of the reverse of olivine crystallisation, but differs because the composition of the added olivine is the same at each step (i.e. being equal to the composition of the host olivine). The amount of olivine melted from the walls during each combination $\mathrm{P} 4+\mathrm{P} 1 \mathrm{~b}$ is recorded during calculations.

\section{References}

Anderson AT (1974) Evidence for a picritic, volatile-rich magma beneath Mt. Shasta, California. J Petrol 15: 243-267

Barsdell M (1988) Petrology and petrogenesis of clinopyroxene-rich tholeiitic lavas, Merelava volcano, Vanuatu. J Petrol 29: 927 964

Bowen NL (1928) The evolution of the igneous rocks. Dover, New York, p 334

Chakraborty S (1997) Rates and mechanisms of Fe-Mg interdiffusion in olivine at $980-1300{ }^{\circ} \mathrm{C}$. J Geophy Res 102B: $12317-$ 12331

Crawford AJ, Falloon TJ, Eggins S (1987) The origin of island arc high-alumina basalts. Contrib Mineral Petrol 97: 417-430

Danyushevsky LV, Sobolev AV (1996) Ferric-ferrous ratio and oxygen fugacity calculations for primitive mantle-derived melts: calibration of an empirical technique. Mineral Petrol 57: 229241

Danyushevsky LV, Sobolev AV, Falloon TJ (1995) North Tongan high-Ca boninite petrogenesis: the role of Samoan plume and subduction zone-transform fault transition. J Geodynamics 20: 219-241

Danyushevsky LV, Sobolev AV, Kononkova NN (1992) Methods of studying melt inclusions in minerals during investigations on water-bearing primitive mantle melts (Tonga trench boninites). Geochem Int 29: 48-62

Della-Pasqua FN (1997) Primitive ankaramitic magmas in volcanic arcs: evidence from melt inclusions. PhD Thesis, University of Tasmania

Della-Pasqua FN, Varne R (1997) Primitive ankaramitic magmas in volcanic arcs: a melt inclusion approach. Can Mineral 35: 291-312 
Eggins S (1993) Origin and differentiation of picritic arc magmas, Ambae (Aoba), Vanuatu. Contrib Mineral Petrol 114: 79-100

Falloon TJ, Green DH (1986) Glass inclusions in magnesian olivine phenocrysts from Tonga: evidence for highly refractory parental magmas in the Tonga arc. Earth Planet Sci Lett 81: 95-103

Foden JD (1983) The petrology of the calcalkaline lavas of Rinjani volcano, east Sunda arc: a model for island arc petrogenesis. J Petrol 24: 98-130

Ford CE, Russel DG, Craven JA, Fisk MR (1983) Olivine-liquid equilibria: temperature, pressure and composition dependence of the crystal/liquid cation partition coefficients for $\mathrm{Mg}, \mathrm{Fe}^{2+}$, $\mathrm{Ca}$ and Mn. J Petrol 24: 256-265

Gurenko AA, Sobolev AV, Kononkova NN (1992) New petrological data on Icelandic rift alkali basalts. Geochem Int 29: 41-53

Gurenko AA, Sobolev AV, Polyakov AI, Kononkova NN (1988) Primary melt of rift tholeiites of Iceland: composition and conditions of crystallisation. Trans (Doklady) USSR Acad Sci 301(4): 109-113

Kamenetsky VS, Metrich N, Cioni R (1995a) Potassic primary melts of Vulsini (Roman Province): evidence from mineralogy and melt inclusions. Contrib Mineral Petrol 120: 186-196

Kamenetsky VS, Sobolev AV, Joron JL, Semet MP (1995b) Petrology and geochemistry of Cretaceous ultramafic volcanics from eastern Kamchatka. J Petrol 36: 637-662

Kamenetsky VS, Crawford AJ, Eggins S, Muhe R (1997) Phenocryst and melt inclusion chemistry of near-axis seamounts, Valu Fa Ridge, Lau Basin: insight into mantle wedge melting and addition of subduction components. Earth Planet Sci Lett 151: 205-223

Lange RA, Carmichael ISE (1987) Densities of $\mathrm{Na}_{2} \mathrm{O}-\mathrm{K}_{2} \mathrm{O}-\mathrm{CaO}-$ $\mathrm{MgO}-\mathrm{FeO}-\mathrm{Fe}_{2} \mathrm{O}_{3}-\mathrm{Al}_{2} \mathrm{O}_{3}-\mathrm{TiO}_{2}-\mathrm{SiO}_{2}$ liquids: new measurements and derived partial molar properties. Geochim Cosmochim Acta 51: 2931-2946

Lee J, Stern RJ (1998) Glass inclusions in Mariana Arc phenocrysts: a new perspective on magmatic evolution in a typical intra-oceanic arc. J Geol 106: 19-33

Niu Y, Batiza R (1991) In situ densities of MORB melts and residual mantle: Implications for buoyancy forces beneath midocean ridges. J Geol 99: 767-775

Portnyagin MV, Danyushevsky LV, Kamenetsky VS (1997) Coexistence of two distinct mantle sources during formation of ophiolites: a case study of primitive pillow-lavas from the lowest part of the volcanic section of the Troodos Ophiolite, Cyprus. Contrib Mineral Petrol 128: 287-301

Ramsay WRH, Crawford AJ, Foden JD (1984) Field setting, mineralogy, chemistry and genesis of arc picrites, New Georgia, Solomon Islands. Contrib Mineral Petrol 88: 386-402
Roedder E (1979) Origin and significance of magmatic inclusion. Bull Minéral 102: 487-510

Roedder E (1984) Fluid inclusions. Rev Mineral 12

Roeder PL, Emslie RF (1970) Olivine-liquid equilibrium. Contrib Mineral Petrol 29: 275-289

Scowen PAH, Roeder PL, Helz RT (1991) Reequilibration of chromite within Kilauea Iki lava lake, Hawaii. Contrib Mineral Petrol 107: 8-20

Sinton CW, Christie DM, Coombs VL, Nielsen RL, Fisk MR (1993) Near primary melt inclusions in anorthite phenocrysts from the Galapagos Platform. Earth Planet Sci Lett 119: 527 537

Sisson TW, Bronto S (1998) Evidence for pressure-release melting beneath magmatic arcs from basalt at Galungnung, Indonesia. Nature 391: 883-886

Sisson TW, Layne GD (1993) $\mathrm{H}_{2} \mathrm{O}$ in basalt and basaltic andesite glass inclusions from four subduction-related volcanoes. Earth Planet Sci Lett 117: 619-635

Sobolev AV, Danyushevsky LV (1994) Petrology and geochemistry of boninites from the North termination of the Tonga trench: constraints on the generation conditions of primary high-Ca boninite magmas. J Petrol 35: 1183-1211

Sobolev AV, Slutskiy AB (1984) Composition and crystallisation conditions of the initial melt of the Siberian meimechites in relation to the general problem of the ultrabasic magmas. Sov Geol Geophys 25: 93-104

Sobolev AV, Dmitriev LV, Baruskov VL, Nevsorov VN, Slutsky AB (1980) The formation conditions of the high-magnesium olivines from the monomineralic fraction of Luna 24 regolith. Proceedings of the 11th Lunar Sci Conf, pp 105-116

Sobolev AV, Danyushevsky LV, Dmitriev LV, Suschevskaya NM (1989) High-alumina magnesian tholeiite as the primary basalt magma at Midocean ridge. Geochem Int 26: 128-133

Sobolev AV, Portnyagin MV, Dmitriev LV, Tsamerian OP, Danyushevsky LV, Kononkova NN, Shimizu N, Robinson PT (1993) Petrology of ultramafic lavas and associated rocks of the Troodos Massif, Cyprus. Petrology 1: 331-361

Tait S (1992) Selective preservation of melt inclusions in igneous phenocrysts. Am Mineral 77: 146-155

Ulmer P (1989) The dependence of the $\mathrm{Fe}^{2+}-\mathrm{Mg}$ cation-partitioning between olivine and basaltic liquid on pressure, temperature and composition. An experimental study to 30 kbar. Contrib Mineral Petrol 101: 261-273

Walker DA, Cameron WE (1983) Boninite primary magmas: evidence from the Cape Vogel peninsula, PNG. Contrib Mineral Petrol 83: $150-158$ 